\title{
Refining temperature reconstructions with the Atlantic coral Siderastrea siderea
}

By Kristine L. DeLong ${ }^{1,2 *}$, Christopher R. Maupin ${ }^{3,4,5}$, Jennifer A. Flannery ${ }^{2}$, Terrence M. Quinn $^{3,4}$, and Chuan-Chou Shen ${ }^{6}$

${ }^{1 *}$ Department of Geography and Anthropology, Louisiana State University, 227 Howe-Russell Geoscience Complex, Baton Rouge, LA 70803, USA, kdelong@1su.edu

${ }^{2}$ U.S. Geological Survey, 600 4th Street South, St. Petersburg, FL 33701, USA, jflannery@usgs.gov

${ }^{3}$ Institute for Geophysics, Jackson School of Geosciences, University of Texas at Austin, J.J. Pickle Research Campus, Building 196, 10100 Burnet Road R2200, Austin, TX 78758, USA, quinn@utig.ig.utexas.edu

${ }^{4}$ Department of Geological Sciences, Jackson School of Geosciences, University of Texas at Austin, 1 University Station C1100, Austin, TX 78712, USA

${ }^{5}$ Department of Geography, Texas A\&M University, 810 Eller O\&M Building MS 3147, College Station, Texas 77843-3147, USA, crmaupintx@tamu.edu

${ }^{6}$ High-precision Mass Spectrometry and Environment Change Laboratory (HISPEC), Department of Geosciences, National Taiwan University, No. 1, Sec. 4, Roosevelt Road, Taipei, Taiwan 10617, ROC, river@ntu.edu.tw

* Corresponding author: kdelong@lsu.edu

Submitted to Palaeogeography, Palaeoclimatology, Palaeoecology on April 2016, revised and resubmitted August 2016.

Keywords: Siderastrea siderea, $\mathrm{Sr} / \mathrm{Ca}, \delta^{18} \mathrm{O}, \delta^{13} \mathrm{C}$, Dry Tortugas, Sea surface temperature 


\begin{abstract}
Developing coral-based temperature reconstructions for a particular coral species requires determining the optimal sampling path orientation and resolution for geochemical analysis to avoid sampling artifacts and to increase reproducibility. Furthermore, a robust coral archive should have high intracolony and intercolony reproducibility for determining the common environmental signal. Here we assessed sampling path orientation and sampling resolution for Siderastrea siderea colonies within the Dry Tortugas National Park in the Gulf of Mexico $\left(24^{\circ} 42^{\prime} \mathrm{N}, 82^{\circ} 48^{\prime} \mathrm{W}\right)$ to determine the optimal sampling protocol and to assess reproducibility of coral $\mathrm{Sr} / \mathrm{Ca}, \delta^{18} \mathrm{O}$, and $\delta^{13} \mathrm{C}$. We identified a sampling artifact due to extracting samples from the coral columella resulting in cold bias up to $5.2^{\circ} \mathrm{C}$ in coral $\mathrm{Sr} / \mathrm{Ca}$. We found no shift to higher coral $\mathrm{Sr} / \mathrm{Ca}$ values (i.e., colder) for years with a $50 \%$ reduction in average extension rate $(2.1 \mathrm{~mm}$ year ${ }^{-1}$ ) or for sampling along paths up to $70^{\circ}$ off the vertical axis of the colony. Our sampling resolution comparison (1900-1993) indicated that the resolution of $\sim 6$ samples year $^{-1}$ used in a $^{-19}$ previous study for coral $\mathrm{Sr} / \mathrm{Ca}$ and $\delta^{18} \mathrm{O}$ may not capture seasonal extremes and thus produces muted seasonal cycles, but that resolution is not biased towards one season. Reproducibility or average deviations, assessed using absolute differences (AD) and root mean square (RMS), among the monthly resolved coral $\mathrm{Sr} / \mathrm{Ca}$ records for intracolony to intercolony comparisons were within $2 \sigma$ of our analytical precisions. Average deviations were reduced by 19 to $61 \%$ when assessing interannual variability (36-month smoothed and mean annual) suggesting that subannual dating uncertainties (i.e., assigning a coral $\mathrm{Sr} / \mathrm{Ca}$ value to a particular month) were the largest source of error in our monthly resolved coral $\mathrm{Sr} / \mathrm{Ca}$ reconstruction. Similarly, coral $\delta^{18} \mathrm{O}$ was reproducible within $2 \sigma$ of our analytical precision $(\mathrm{AD}=0.10 \%$ and $\mathrm{RMS}=0.07 \%$ ); however, coral $\delta^{13} \mathrm{C}$ and linear extension records were not reproducible. Our assessment of coral
\end{abstract}


geochemical variations from multiple $S$. siderea colonies suggests this species is suitable for paleoclimatic reconstructions, including subfossil corals and microatoll colonies that grow laterally. 
$8 / 9 / 16$

\section{Introduction}

A coral colony is comprised of many living polyps located on the surface of the colony residing on top of and within skeletal corallites that the polyps extend incrementally with time by the process of calcification (Barnes, 1973). Each corallite contains a less dense center with vertical plates of septo-costae surrounded by thicker and denser walls (Veron, 2000). The size and structure of corallites vary with genera and species, which are used to identify the coral species (Veron, 1986). Coral colonies have several types of morphologies including bouldershaped massive corals, pillar-shaped columnar corals, and branching corals (Veron, 2000). Branching corals are among the fastest growing $\left(\sim 100 \mathrm{~mm} \mathrm{year}^{-1}\right)$ and massive corals are among the slower growing (up to $25 \mathrm{~mm}$ year $^{-1}$ ) (Veron, 1995). Skeletons of massive corals have low and high-density bands that form on a yearly basis thus providing a "calendar" to establish the passage of time (Knutson et al., 1972). Massive corals can live for several centuries and their aragonitic skeletons provide an excellent archive for reconstructing past environmental variations from their skeletal chemistry (see reviews of Druffel, 1997; Gagan et al., 2000; Felis and Patzold, 2004; Corrège, 2006; Grottoli and Eakin, 2007; Jones et al., 2009; Lough, 2010; Sadler et al., 2014; Bradley, 2015).

Geochemical artifacts related to sampling different skeletal elements of an individual corallite have been reported for the massive corals Montastraea faveolata and M. annularis ${ }^{1}$ (Leder et al., 1996; Smith et al., 2006), Diploria strigosa (Giry et al., 2010), and Diploastrea heliopora (Watanabe et al., 2003; Bagnato et al., 2004; Dassié and Linsley, 2015). The Atlantic

${ }^{1}$ The systematics of the Montastraea or Montastrea complex (M. faveolata, $M$. annularis, and $M$. franski) have varied with reclassifications, in which $M$. faveolata and $M$. annularis are sometimes interchanged (Knowlton and Budd, 2001). A recent reclassification moves faveolata and annularis to the genus Orbicella with $M$. franski remaining unchanged (Budd et al., 2012). For clarity, we use the species name from the original study when referring to that study. 
coral M. faveolata has larger polyps ( 2-3 mm diameter) with less dense central columella and thick higher density parathecal corallite walls that are typically sampled for geochemical analysis. Sampling along horizontal paths parallel to the density bands in $M$. faveolata revealed large variations among skeletal elements equivalent to $2{ }^{\circ} \mathrm{C}$ with shifts to higher coral $\mathrm{Sr} / \mathrm{Ca}$ values (i.e., colder) in the columella (Smith et al., 2006). A study with coral $\delta^{18} \mathrm{O}$ found similar results for M. annularis (Leder et al., 1996). An assessment of sampling different skeletal elements in the Atlantic coral D. strigosa revealed a shift to higher coral $\mathrm{Sr} / \mathrm{Ca}$ and $\delta^{18} \mathrm{O}$ values, up to $6{ }^{\circ} \mathrm{C}$ colder for coral $\mathrm{Sr} / \mathrm{Ca}$, when sampling off of the corallite wall (Giry et al., 2010). Diploria strigosa is a brain coral (meandroid) with large, linear corallites, a continuous columella, and high-density septathecal corallite walls. Conversely, studies with the massive Pacific coral $D$. heliopora found sampling along the columella in the center of the corallite produced larger seasonal variations in coral $\delta^{18} \mathrm{O}$ and $\mathrm{Sr} / \mathrm{Ca}$ compared to the septa walls and therefore the columella is the optimal sampling location for that species (Watanabe et al., 2003; Bagnato et al., 2004; Dassié and Linsley, 2015). Diploastrea heliopora has larger polyps ( 10 $\mathrm{mm}$ diameter) with radial septa that thicken towards to corallite edges forming pronounced synapticulothecal walls.

Massive Porites spp., which are typically used for paleoclimatic reconstructions, have small corallites ( $\sim 1 \mathrm{~mm}$ diameter) with even smaller thecal walls and columella, which may or may not be present in some Porites species (Veron, 1986). Individual sampling volume ( 1-2 $\mathrm{mm}^{3}$ ) for Porites spp. includes more than one corallite and all corallite skeletal elements; to date, no geochemical bias has been reported for any one particular Porites corallite skeletal element. However, these massive corals have centimeter-scale skeletal structures with numerous corallites in fan-like structures with "valleys" in between the fans (Darke and Barnes, 1993). Studies that 
sampled Porites corals in these valleys found a cold bias in coral $\mathrm{Sr} / \mathrm{Ca}$ and $\delta^{18} \mathrm{O}$ determinations (Alibert and McCulloch, 1997; Cohen and Hart, 1997; DeLong et al., 2013). Additionally, studies that examined Porites lutea found that the extending corallite walls not oriented parallel to the sampling or slab surface can produce a warm bias up to $2.3{ }^{\circ} \mathrm{C}$ (DeLong et al., 2007; DeLong et al., 2013; Zinke et al., 2016). In summary, the corallite "skeletal element" geochemical bias appears to be present in coral species with larger corallites $(>2 \mathrm{~mm}$ in diameter) that are sampled along a single skeletal element (corallite wall or columella) whereas corals with smaller corallites $(<2 \mathrm{~mm}$ in diameter) tend to have a "corallite structure" bias. Therefore, each coral species should be assessed for optimal sampling methods and to identify any potential sampling artifacts among skeletal elements and corallite structures.

Additionally, the sampling resolution used to extract a geochemical time series from a coral skeleton may introduce problems such as failure to record seasonal extremes, reduced seasonal cycles, and seasonal bias. For coral $\mathrm{Sr} / \mathrm{Ca}$ and $\delta^{18} \mathrm{O}$ in $P$. lutea, sampling resolutions of 4 samples year ${ }^{-1}$ resulted in a failure to capture winter extremes, reduced amplitude in seasonal cycles, and a bias towards summer months whereas resolutions of 30 and 12 samples year $^{-1}$ resulted in the same seasonal cycle (Quinn et al., 1996; DeLong et al., 2007). For Montastraea spp., approximately weekly sampling resolution may be needed to recover the full annual cycle in coral $\delta^{18} \mathrm{O}$ and $\mathrm{Sr} / \mathrm{Ca}$ (Leder et al., 1996; Swart et al., 2002). Sampling resolution should be assessed for each geochemical proxy and coral species because optimal sampling technique varies with genera and species.

Early studies with Pavona clavus corals (columnar morphology) suggested sampling off the vertical axis of the colony, where growth rates are reduced on the sides of the colony, resulted in a mean shift to higher coral $\mathrm{Sr} / \mathrm{Ca}$ and $\delta^{18} \mathrm{O}$ values for extension rates less than $5 \mathrm{~mm}$ 
year $^{-1}$ (McConnaughey, 1989; de Villiers et al., 1994). Those studies prompted the sampling of the "major growth axis" or the vertical axis of the colony for geochemical analysis to avoid possible kinetic or growth-related effects. Further investigations with massive Porites spp., including laterally growing microatolls, found no bias in coral $\mathrm{Sr} / \mathrm{Ca}$ or $\delta^{18} \mathrm{O}$ for horizontal sampling path orientations in colonies with extension rates greater than $5 \mathrm{~mm} \mathrm{year}^{-1}$ (Alibert and McCulloch, 1997; Woodroffe, 2000; Mitsuguchi et al., 2003; Maier et al., 2004; Felis et al., 2009; McGregor et al., 2011; DeLong et al., 2013; Wu et al., 2013). Similarly, no difference in coral $\delta^{18} \mathrm{O}$ was found between the top and the side of a massive $M$. annularis colony with growth rates between 1.4 and $8.1 \mathrm{~mm}^{-1}$ year $^{-1}$ (Leder et al., 1996). Other studies suggest that thresholds for growth-related effects vary with genera and species because skeletal density (product of calcification rate and linear extension rate) varies with species (DeLong et al., 2011; DeLong et al., 2013). Regardless, sampling the vertical axis remains the de facto standard for coral geochemical studies (Corrège, 2006; Jones et al., 2009; Sadler et al., 2014). However, use of microatolls that grow laterally or subfossil corals with unknown growth orientation for paleoclimatic reconstructions is a compelling reason to test the validity of this premise.

If we assume coral $\mathrm{Sr} / \mathrm{Ca}, \delta^{18} \mathrm{O}$, and $\delta^{13} \mathrm{C}$ variations are environmental signals, then coral colonies of the same species in the same environmental setting (i.e., water depth, location) should record the similar geochemical variations within analytical precision. In this study, we assessed reproducibility of coral $\mathrm{Sr} / \mathrm{Ca}, \delta^{18} \mathrm{O}$, and $\delta^{13} \mathrm{C}$ in $\mathrm{S}$. siderea on spatial scales from within a colony to between reef sites, and on temporal scales ranging from monthly to decadal. Before performing these assessments, we defined ideal sampling methods for $S$. siderea and determine the optimal sampling resolution for extracting monthly temperature records from coral skeletal material. Calibration of coral $\mathrm{Sr} / \mathrm{Ca}$ to temperature for these corals along with their climate 
interpretation was reported in DeLong et al. (2014) as well as an assessment of extension rates.

\section{Materials and Methods}

This report examined $S$. siderea cores (08PS-A1, 08PS-A2, 08PS-F1, 93DRYSS1, and 93DRYSS2) from previous studies that give descriptions of colony locations (Supplementary Fig. S1), core recovery and processing, and chronology development (Supplementary Figs. S24) (Maupin et al., 2008; DeLong et al., 2011; Hickey et al., 2013; DeLong et al., 2014). Two of the cores have unknown ages and were dated using high precision ${ }^{230} \mathrm{Th}$ dating (Shen et al., 2008; Shen et al., 2012); results reported in DeLong et al. (2014). For our sampling resolution assessment, we used a coral core 93DRYSS1 that was sampled at $\sim 6$ samples year $^{-1}$ in a previous study (Maupin et al., 2008).

Samples for geochemical analysis $(300-500 \mu \mathrm{g})$ were extracted from each slab surface using a computer-driven micromill system (Taig Micromill with SuperCAM software from Supertech and Associates, Phoenix, AZ) described by Quinn et al. (1996) and modified by DeLong et al. (2011). Samples were extracted continuously at approximately monthly increments (Table 1) with a $1.0 \mathrm{~mm}$ diameter dental drill bit at a sampling depth of $1.0 \mathrm{~mm}$ with the exception of 93DRYSS1 that was sampled with a $1.4 \mathrm{~mm}$ diameter drill bit in a $2 \mathrm{~mm}$ wide and $1.5 \mathrm{~mm}$ deep path (Maupin et al., 2008). Divots (1.5 $\mathrm{mm}$ deep) were milled into the coral slab at regular intervals along sampling paths for aligning geochemical samples to scans of the slab and X-radiographs (Supplementary Figs. S2-4). Sampling paths were selected, after examination of the coral slab under a microscope, parallel to the extending corallites along the synapticulothecal corallite wall, the optimal sampling location for this species (Maupin et al., 2008; DeLong et al., 2011; DeLong et al., 2014). Cores 08PS-A1 and 08PS-A2 were sampled at the United States Geological Survey (USGS) St. Petersburg Coastal and Marine Science Center 
(SPCMSC) in Florida whereas the cores 93DRYSS1 and 93DRYSS2 were sampled at the University of South Florida (USF) and University of Texas (UT) at Austin, respectively. Multiple researchers with different experience levels at UT and Louisiana State University (LSU) sampled the core 08PS-F1. Samples were split for isotopic and trace elemental analyses. Monthly-resolved coral $\mathrm{Sr} / \mathrm{Ca}$ was determined for the entire cores whereas isotopic analysis $\left(\delta^{18} \mathrm{O}\right.$ and $\left.\delta^{13} \mathrm{C}\right)$ was determined for a select interval in two cores for reproducibility assessments. Elemental ratio determinations $(\mathrm{Sr} / \mathrm{Ca}$ and $\mathrm{Mg} / \mathrm{Ca})$ were made using a PerkinElmer 4300 Inductively Coupled Plasma Optical Emission Spectrometer (ICP-OES) at the Analytical Laboratory for Paleoclimate Studies (ALPS) at UT and a PerkinElmer 7300 ICP-OES at the USGS SPCMSC. The UT ICP-OES was formerly at the College of Marine Science at USF and is the same instrument used by Maupin et al. (2008). A laboratory internal gravimetrical standard (IGS) was measured before and after each dissolved coral sample to correct for instrumental drift (Schrag, 1999). The average drift-corrected IGS precision for $\mathrm{Sr} / \mathrm{Ca}$ was $0.025 \mathrm{mmol} \mathrm{mol}{ }^{-1}(2 \sigma$, $n=862 ; \mathrm{UT})$ and $0.024 \mathrm{mmol} \mathrm{mol}^{-1}(2 \sigma, n=212$; USGS). The average drift-corrected precision for $\mathrm{Sr} / \mathrm{Ca}$ of homogenized powder from a $P$. lutea $(\mathrm{PL})$ coral used as a coral standard was 0.030 $\mathrm{mmol} \mathrm{mol}^{-1}\left(2 \sigma, n=1194\right.$; UT) and $0.039 \mathrm{mmol} \mathrm{mol}^{-1}(2 \sigma, n=286$; USGS). The absolute value of $\mathrm{Sr} / \mathrm{Ca}$ for IGS and PL has been confirmed by thermal ionization mass spectrometry at the University of Minnesota Isotope Laboratory (Kilbourne et al., 2004; Quinn et al., 2006). Sr/Ca values determined for IGS, PL, and aliquots of the same coral samples at these laboratories are consistent within analytical error (DeLong et al., 2011; 2014). Coral Mg/Ca was measured (data not shown) to detect possible diagenesis (Quinn and Taylor, 2006) but was not assessed for reproducibility since it is not a robust temperature proxy.

Isotopic ratio analyses $\left(\delta^{18} \mathrm{O}\right.$ and $\left.\delta^{13} \mathrm{C}\right)$ were made using a Thermo Delta $\mathrm{V}$ connected to 
a Kiel IV carbonate device at ALPS. Coral samples were dissolved in phosphoric acid at $70^{\circ} \mathrm{C}$. Average external precision for 08PS-F1 was $\pm 0.06 \%$ for $\delta^{18} \mathrm{O}$ and $\pm 0.02 \%$ for $\delta^{13} \mathrm{C}(1 \sigma, n=11$, NBS-19) and for 08PS-A1 was $\pm 0.08 \%$ for $\delta^{18} \mathrm{O}$ and $\pm 0.03 \%$ for $\delta^{13} \mathrm{C}(1 \sigma, n=51$, Estremoz). Isotopic values are reported in delta notation $(\delta)$ relative to the Vienna PeeDee Belemnite (VPDB) isotopic standard.

Core chronologies were developed by assigning maximum coral $\mathrm{Sr} / \mathrm{Ca}$ values to minimum sea surface temperature (SST) values and vice versa for each annual cycle (see DeLong et al., 2014 for details). The chronology for coral Sr/Ca was applied to the other geochemical records $\left(\mathrm{Mg} / \mathrm{Ca}, \delta^{18} \mathrm{O}\right.$, and $\left.\delta^{13} \mathrm{C}\right)$ and sample location down core or depth using Analyseries software (Paillard et al., 1996) and then linearly interpolated to even monthly intervals. Monthly core depth records were used to calculate annual linear extension between maxima in coral $\mathrm{Sr} / \mathrm{Ca}$ (i.e., February to February), for which precision is limited by sampling resolution (Table 1). This method removes the subjectivity of measuring distance between indistinct shifts in high to low-density areas in the X-radiographs (Supplementary Figs. S2-4) and is directly comparable to the geochemical variations.

Reproducibility was assessed using two tests of average deviations on various time scales for coral Sr/Ca, $\delta^{18} \mathrm{O}$, and $\delta^{13} \mathrm{C}$. Root-mean-squared (RMS) is the sum of the deviations of coral geochemical determinations $\left(\mathrm{coral}_{\mathrm{i}}\right)$ from the mean of those determinations ( $\left.\mathrm{coral}_{\text {mean }}\right)$ for any single month normalized by the number of observations for that month ( $n$; Eq. 1$)$, which assumes the mean is a good estimate of the true coral value for that month (DeLong et al., 2013).

$$
\mathrm{RMS}=\left(\sum\left(\text { coral }_{\mathrm{i}}-\text { coral }_{\text {mean }}\right)^{2} / n\right)^{1 / 2} \quad \text { (Eq. 1) }
$$

Absolute difference (AD) is a measure of the discrepancy between coral geochemical determinations ( $\operatorname{coral}_{1}$ and $\operatorname{coral}_{2}$ ) for any single month (Eq. 2) for which the true value is 
unknown (DeLong et al., 2007; DeLong et al., 2013).

$$
\mathrm{AD}=2^{-1 / 2}\left|\operatorname{coral}_{1}-\operatorname{coral}_{2}\right| \quad \text { (Eq. 2) }
$$

Pearson correlation coefficient $(r)$ is not an indicator of discrepancy but it is useful for determining if two time series contain a common signal or covary. To account for serial correlation in quasi-sinusoidal monthly time series, degrees of freedom (df) was determined by the Runs test (Draper and Smith, 1998) and was used instead of the number of observations. Other statistical tests used include the Student's $t$-test and $F$-test. Significance testing assumed a 95\% confidence interval. Time series were smoothed with a low-pass finite impulse response (LPFIR) filter (Bloomfield, 2000). Coral Sr/Ca-SST was determined using the transfer function $\left(-0.044 \mathrm{mmol} \mathrm{mol}^{-1}{ }^{\circ} \mathrm{C}^{-1}\right)$ for these corals (DeLong et al., 2014).

\section{Results and Discussion}

\subsection{Sampling artifacts}

\subsubsection{Slab extraction from a core}

For $S$. siderea, the optimal sampling path is one that follows an extending corallite as it grew with time (Maupin et al., 2008; DeLong et al., 2011; DeLong et al., 2014). Extracting a coral slab from a cylindrical core requires close examination of the core surface to discern the orientation of the corallites inside the core; a coral core is not a sediment core that can be cut at any orientation. For S. siderea, look for the cross-sections of the top of corallites to discern direction of growth. Cut the slab where the tops of the corallites are visible on the top or side of the core; this will transect the corallites along the growth axis. An example of a core slab cut at an improper angle appears in Fig. 1 on the left. Examination of the slab surface under magnification reveals oblong tops of corallites where radiating septa are visible from the center of the corallites. The corallite angle with respect to slab surface is $\sim 21^{\circ}$ at the top of the slab and 
$\sim 33^{\circ}$ at the bottom. The X-radiograph of this slab has a wavy appearance with indistinct annual density bands and corallite walls varying in density. Measurements of annual extension with this slab would be greater than the actual linear extension since the corallites are at an angle with respect to the slab surface. A properly cut slab appears on the right of Fig. 1 and its X-radiograph has more distinct and continuous density bands, and the corallite walls are straight and continuous with the same density. Examining this slab under magnification reveals longitudinal transects of the synapticulothecal corallite walls that are needed for extracting a continuous time series of coral geochemical variability.

Cutting a slab from an entire core section properly may be difficult for some cores. In 08PS-A1-A we cut two slabs, one with suboptimal alignment in the lower $2 / 3$ of the slab (Supplementary Fig. S2). The corallite angle increases to $18^{\circ}$ with respect to the slab surface and the annual density bands appear wavy without clear, discernable bands. We abandoned sampling slab 2 from 08PS-A1 at 1985 (Supplementary Fig. S2) once the corallites were no longer parallel to the slab surface. Nevertheless, we do not find any coral $\mathrm{Sr} / \mathrm{Ca}$ bias between the sampling paths on 08PS-A1 slabs 2 and 3.

\subsubsection{Corallite skeletal structures}

We sampled three paths parallel to the density bands in 08PS-A2 to assess coral $\mathrm{Sr} / \mathrm{Ca}$ variability across corallites and their skeletal elements (Fig. 2 and Supplementary Fig. S2), similar to the previous study with M. faveolata (Smith et al., 2006). The mean of the coral Sr/Ca determinations from the cyan path is greater $\left(9.051 \mathrm{mmol} \mathrm{mol}^{-1}\right.$ on average $)$ than the other two paths (8.964 and $8.931 \mathrm{mmol} \mathrm{mol}^{-1}$ on average for green and magenta paths, respectively); therefore, the cyan path represents a colder interval (Fig. 2C). Examination of the X-radiograph reveals the cyan path lies along the darker area (i.e., low density) between two lighter bands or 
high-density bands (Fig. 2B); therefore, the low-density bands formed in the winter. The cyan path has the lowest standard deviation or variability $\left(0.059 \mathrm{mmol} \mathrm{mol}^{-1}, 1 \sigma\right)$ whereas the magenta path has the highest $\left(0.085 \mathrm{mmol} \mathrm{mol}^{-1}, 1 \sigma\right)$. Along the synapticulothecal corallite walls, the coral $\mathrm{Sr} / \mathrm{Ca}$ determinations have the greatest range of values $(0.256$ and $0.193 \mathrm{mmol}$ $\mathrm{mol}^{-1}$ for samples \#13 and 23) whereas the columella contains a smaller range of values (0.053 and $0.155 \mathrm{mmol} \mathrm{mol}^{-1}$ for samples \#8 and 17). The range in coral $\mathrm{Sr} / \mathrm{Ca}$ determinations along the walls represents 4.4 to $5.8^{\circ} \mathrm{C}$ or $\sim 2 / 3$ of the observed SST seasonal cycle $\left(8.1^{\circ} \mathrm{C}\right)$ and the three sampling paths cover $\sim 2 / 3$ of the annual density band couplet in the X-radiograph.

We sampled five paths or lines parallel to the corallite growth direction in 08PS-F1 to assess coral $\mathrm{Sr} / \mathrm{Ca}$ variability within a corallite (Fig. 3), similar to previous studies using $D$. strigosa (Giry et al., 2010) and M. annularis (Leder et al., 1996). Coral Sr/Ca variations agree within analytical precision with each other and with sampling paths used in the reconstruction (see Supplementary Fig. S3 for locations) except for line 3, which is in the columella, from 1.0 to $1.65 \mathrm{~cm}$ where a shift to higher coral $\mathrm{Sr} / \mathrm{Ca}$ values $\left(0.228 \mathrm{mmol} \mathrm{mol}^{-1}\right.$ on average or $5.2{ }^{\circ} \mathrm{C}$ colder) occurs that is greater than analytical precision. This shift also results in a $20 \%$ reduction in the annual cycle for line 3 . For the same interval, lines 2 and 5 also have a shift to higher coral $\mathrm{Sr} / \mathrm{Ca}$ values but not to the same extreme. Examination of the coral slab (Fig. 3B) reveals line 2 is partially in the columella from 1.0 to $1.7 \mathrm{~cm}$ and line 5 is in the columella from 1.4 to $1.7 \mathrm{~cm}$.

The interval from 1816 to 1820 for 08PS-A2-B has colder summers and a reduced seasonal cycle that did not agree with the coral Sr/Ca determinations from 93DRYSS2 (Fig. 3E). Examination of the coral slab under magnification revealed the sampling path is within the columella. We selected a new sampling path along the corallite wall and these coral $\mathrm{Sr} / \mathrm{Ca}$ determinations agree within analytical precision with those from 93DRYSS2. The mean of the 
suboptimal path $\left(9.102 \pm 0.077 \mathrm{mmol} \mathrm{mol}^{-1}, 1 \sigma\right)$ is greater than that for the optimal path $(9.055$ $\pm 0.090 \mathrm{mmol} \mathrm{mol}^{-1}, 1 \sigma$ ) for the same time interval, a difference of $0.047 \mathrm{mmol} \mathrm{mol}^{-1}$ or $1.1^{\circ} \mathrm{C}$.

The area selected on 08PS-F1 for corallite sampling also has an oblong top of a corallite visible in the coral scan (starting at $\sim 0.8 \mathrm{~cm}$ from core top) at an angle of $\sim 22^{\circ}$ with respect to the slab surface (Fig. 3A). Coral Sr/Ca in line 3 agrees within analytical precision with the other lines from 0 to $0.8 \mathrm{~cm}$ and shifts when it reaches the oblong top of the corallite. The coral $\mathrm{Sr} / \mathrm{Ca}$ values for the lines along the corallite walls and sampling paths in 08PS-F1 used in the reconstruction agree within analytical precision with those from 08PS-A1; however, this interval is quite short for a reproducibility assessment so this corallite angle should not be used without further assessment.

The largest intracolony differences we observed occurred in the interval from 1896 to 1942 between opposing sides of 08PS-F1 with a $0.6^{\circ} \mathrm{C}$ average difference. The angle of the corallites is $13^{\circ}$ with respect to the slab surface for this interval with the elongated tops of corallites visible; however, there is no increase in annual extension or increase in summer values, which were previously noted for $P$. lutea (DeLong et al., 2013). For this interval, the average AD is $0.026 \pm 0.019 \mathrm{mmol} \mathrm{mol}^{-1}\left(1 \sigma\right.$; equivalent to $\left.0.6{ }^{\circ} \mathrm{C}\right)$ between parallel paths on $08 \mathrm{PS}-\mathrm{F} 1$ and the average $\mathrm{AD}$ is $0.029 \pm 0.022\left(1 \sigma\right.$; equivalent to $\left.0.7^{\circ} \mathrm{C}\right)$ between $08 \mathrm{PS}-\mathrm{F} 1$ and $08 \mathrm{PS}-\mathrm{A}$ suggesting a $\sim 0.7^{\circ} \mathrm{C}$ cold bias for sampling corallites at a suboptimal angle. However, the corallites are parallel to the slab surface for the interval from 1930 to 1942 and the average AD is larger $\left(0.035 \pm 0.026 \mathrm{mmol} \mathrm{mol}^{-1}, 1 \sigma\right.$; equivalent to $\left.0.8^{\circ} \mathrm{C}\right)$; therefore, it is unclear if sampling corallites with small angles $\left(<20^{\circ}\right)$ to the slab surface produces a definable bias in S. siderea.

In summary, each $S$. siderea corallite contains a spongy center or columella surrounded by septa (Fig. 3D). Septa from adjacent corallites meet to form a thickened synapticulothecal 
wall, seen as continuous dense areas in X-radiographs perpendicular to annual density bands. If the sampling path shifts off of the synapticulothecal wall into the columella, the coral $\mathrm{Sr} / \mathrm{Ca}$ values will be greater than adjacent $\mathrm{Sr} / \mathrm{Ca}$ values on the wall and similar to winter $\mathrm{Sr} / \mathrm{Ca}$ values extracted along the corallite wall, resulting in a reduced seasonal cycle, similar to that noted for coral $\mathrm{Sr} / \mathrm{Ca}$ and $\delta^{18} \mathrm{O}$ in D. strigosa (Giry et al., 2010) and coral $\delta^{18} \mathrm{O}$ in $M$. annularis (Leder et al., 1996). The optimal sampling path for $S$. siderea is along the corallite wall avoiding the columella. Slabbing a core perfectly along the longitudinal cross-sections of the extending corallites may not be possible for the entire length of the core; additional slabs may be needed. Corallites at an angle of $13^{\circ}$ or less do not appear to cause a shift in coral $\mathrm{Sr} / \mathrm{Ca}$ at least within our analytical precision. Larger corallite angles $\left(>20^{\circ}\right)$ with respect to the slab surface should be avoided unless reproducibility is assessed.

\subsubsection{Sampling resolution}

The study of Maupin et al. (2008) sampled a S. siderea coral from Dry Tortugas (93DRYSS1; see Supplementary Fig. S1 for location) at $\sim 6$ samples year $^{-1}$ from 1900 to 1993 (Table 1). They assessed the effect of sampling resolution ( $\sim 6$ samples year $^{-1}$ and $\sim 18$ samples year $^{-1}$ ) for coral $\mathrm{Sr} / \mathrm{Ca}$ in a random three-year interval and found no difference within analytical precision for the sampling resolutions tested. We extend their sampling resolution assessment by comparing our monthly resolved coral $\mathrm{Sr} / \mathrm{Ca}$ variations from two cores (08PS-A1 and 08PS-F1) with their bimonthly resolved coral Sr/Ca record for the longer interval from 1900 to 1993 (Fig. 4A). The mean for 93DRYSS1 $\left(8.999 \pm 0.103 \mathrm{mmol} \mathrm{mol}^{-1}, 1 \sigma\right)$ is similar to the means for 08PSA1 and 08PS-F1 for the same interval $\left(8.999 \pm 0.123 \mathrm{mmol} \mathrm{mol}^{-1}, 1 \sigma\right.$, and $9.021 \pm 0.122 \mathrm{mmol}$ $\mathrm{mol}^{-1}, 1 \sigma$; respectively); however, the standard deviation is reduced by $16 \%$ and the average amplitude of the seasonal cycle $\left(0.266 \pm 0.046 \mathrm{mmol} \mathrm{mol}^{-1}, 1 \sigma\right)$ is reduced by as much as $38 \%$ 
for the bimonthly record. There are several years where either the bimonthly summer minima in $\mathrm{Sr} / \mathrm{Ca}$ are colder (12 out of 93 years or $12.9 \%$ ) or winter maxima are warmer (29 years out of 93 years or $31.2 \%$ ) than that observed in the monthly resolved cores and these differences are greater than analytical precision (e.g., 1977, 1979, 1981, 1984, and 1985 in Fig. 4A). In one instance, the bimonthly $\mathrm{Sr} / \mathrm{Ca}$ summer extreme is warmer than that observed in the other cores (1992), which is close to the top of that core. We found that some of the intervals with disagreements between sampling resolutions are years in 93DRYSS1 with slower extension rates (e.g., 1913-1915, 1968-1969, and 1984-1985), thus an effective sampling resolution of less than 6 samples year $^{-1}$.

We identified 15 years with slower extension rates $\left(\leq 2.6 \mathrm{~mm} \mathrm{year}^{-1}\right.$ or $\left.>2 \sigma\right): 2$ years from 08PS-F1, 9 years from 08PS-A2, and 4 years from 93DRYSS2. In general, the coral Sr/Ca determinations for these slower extension years are within $2 \sigma$ of our analytical precision with contemporaneous determinations from the other colonies, which had higher extension rates $(>2.6$ mm year ${ }^{-1}$; e.g., 1779, 1784, and 1785 in Fig. 4B). The exception is 1783 for which both cores have slower extension rates yet the coral $\mathrm{Sr} / \mathrm{Ca}$ determinations agree within analytical precision and both cores have an average seasonal cycle. There are three years in core 08PS-A2 (1786, 1787, and 1798 in Fig. 4B) with slower extension rates for which the differences with contemporaneous coral $\mathrm{Sr} / \mathrm{Ca}$ variations are greater than analytical precision. These slower extension years have reduced amplitude in the coral Sr/Ca seasonal cycle but with no evidence of the mean shift in coral Sr/Ca that was previously reported for P. clavus (de Villiers et al., 1994). The slowest extension rate and smallest seasonal cycle in coral $\mathrm{Sr} / \mathrm{Ca}$ for all the cores sampled is 1787 in 08PS-A2 (2.09 $\mathrm{mm} \mathrm{year}^{-1}$ and $0.149 \mathrm{mmol} \mathrm{mol}^{-1}$, respectively). This extension rate coupled with the constant sampling increment (Table 1) resulted in a sampling resolution of 5 
samples year ${ }^{-1}$, less than the sampling resolution for 93DRYSS1; therefore, is a sampling resolution artifact. Resampling this year with a higher resolution sampling increment $(0.17 \mathrm{~mm}$ sample $^{-1}$ ) could confirm our assessment. Lastly, two years (1885 and 1886) with slower extension rates in 08PS-A2 (2.5 and $\left.3.3 \mathrm{~mm}_{\text {year }}^{-1}\right)$ and 93DRYSS2 (3.2 and $2.8 \mathrm{~mm}_{\text {year }}^{-1}$ ) follow the large volcanic eruption Krakatau in August 1883; these are the coldest years in the SST reconstruction (DeLong et al., 2014). There is no evidence that slower extension rates (2.0 to $5.0 \mathrm{~mm}$ year $^{-1}$ ) in $S$. siderea cause a mean shift to higher (i.e., colder) coral $\mathrm{Sr} / \mathrm{Ca}$ values; therefore, these colder temperatures are probably real with the corals reducing their growth. A shorter interval (3 years) was used to assess sampling resolution differences in coral $\delta^{18} \mathrm{O}$ for 93DRYSS1 ( 6 samples year $\left.{ }^{-1}\right)$ and 08PS-A1 ( 12 samples year $\left.{ }^{-1}\right)$ (Fig. 5A). In general, the coral $\delta^{18} \mathrm{O}$ values between 93DRYSS1 and 08PS-A1 are within analytical precision; however, there is a consistent mean shift between these coral $\delta^{18} \mathrm{O}$ records $(0.03 \%$ on average $)$. The study of Maupin et al. (2008) did not find any differences in coral $\delta^{18} \mathrm{O}$ within analytical precision for their sampling resolution assessment ( $\sim 6$ and 18 samples year $\left.{ }^{-1}\right)$. However, the study of Leder et al. (1996) noted the amplitude of the $\delta^{18} \mathrm{O}$ seasonal cycle in $M$. annularis decreased with lower sampling resolution (weekly to monthly resolution). That study also showed that the deeper calyxes of $M$. annularis produced to saw-tooth shaped skeletal deposition pattern for which a larger sampling area would lead to more time integration resulting in a reduced seasonal cycle (see Fig. 2 of Leder et al. (1996)). The study of DeLong et al. (2011) examined a M. faveolata coral (08PS-B3) that grew in close proximity to the corals sampled in this study (Supplementary Fig. S1). They reported a reduced seasonal cycle in coral Sr/Ca for $M$. faveolata compared to $S$. siderea when using approximately the same sampling resolution, thus highlighting the differences in coral species. This coral $\delta^{18} \mathrm{O}$ sampling resolution assessment was 
made for a short interval ( 3 years) and we suggest a longer interval ( $>50$ years) is needed to fully assess the impact of sampling resolution on coral $\delta^{18} \mathrm{O}$ in $S$. siderea, based on our $\mathrm{Sr} / \mathrm{Ca}$ results.

One last consideration is possibility that heat produced during microsampling the coral skeleton $\left(>100{ }^{\circ} \mathrm{C}\right)$ produced calcite thus shifting the coral $\delta^{18} \mathrm{O}$ values (Waite and Swart, 2015) that may not have a constant offset (Gaffey et al., 1991). Our micromilling systems were run at the slowest speed $(1100 \mathrm{rpm})$ with a single pass, which is slower than the New Wave Research micromill (1,200-35,000 rpm) used by Waite and Swart (2015), who report a "50\% drill speed, $30 \%$ approach speed, 3 passes at $50 \mu \mathrm{m}$ per pass." Using an infrared thermometer on the coral surface during micromilling at LSU, the hottest temperature was $27.3^{\circ} \mathrm{C}$. Furthermore, the coral $\delta^{18} \mathrm{O}$ between 08PS-F1 and 08PS-A1 agree within analytical precision (Fig. 9a) for which 08PSA1 and 08PS-F1 were drilled with two different micromill systems at USGS and UT, respectively. If calcite was being produce by the micromilling heat, these two records should have different coral $\delta^{18} \mathrm{O}$ values.

Constant sampling intervals coupled with slower extension rates $(\leq 50 \%$ the average $)$ may introduce sampling artifacts such as a failure to record seasonal extremes and reduced seasonal cycles in proxy records extracted from $S$. siderea corals. Our coral $\mathrm{Sr} / \mathrm{Ca}$ results do not indicate a clear seasonal bias towards winter or summer in S. siderea for lower sampling resolutions, as seen in P. lutea (DeLong et al., 2007), but may be present in coral $\delta^{18} \mathrm{O}$; however, a longer assessment interval is required for a robust assessment. As long as sampling is continuous (no powder left behind), taking fewer samples per year simply means longer time intervals being represented by each sample, so the extremes would be dampened. Siderastrea siderea at this subtropical location is known to calcify $50 \%$ faster (linear extension $\mathrm{x}$ density $=$ calcification rate) in summer compared to winter (Kuffner et al., 2013); however, these corals appear to 
linearly extend with an near constant rate with little seasonal preference suggesting seasonal variability in density, as seen in the annual density bands. Seasonality in linear extension and calcification rates likely varies with latitude; therefore, each location should be assessed. We find no evidence for a shift to higher coral Sr/Ca values (i.e., colder) for slower extension rates (this study ranges from 2.1-6.6 $\mathrm{mm}$ year $^{-1}$ ), as suggested for the columnar P. clavus (de Villiers et al., 1994). S. siderea is a denser coral $\left(3.7 \mathrm{~g} \mathrm{~cm}^{-3}\right.$ (Kuffner et al., 2013)) compared to Porites spp. (1.1-1.6 $\mathrm{g} \mathrm{cm}^{-3}$ ) (Risk and Sammarco, 1991) and P. clavus (1.44-1.86 $\left.\mathrm{g} \mathrm{cm}^{-3}\right)$ (Hughes, 1987) and thus calcification rates are comparable regardless of annual linear extension rates. Since skeletal density varies among corals species, extrapolation of threshold extension rates (e.g., $<5$ $\mathrm{mm}_{\text {year }}^{-1}$ for Porites) should not be made to other species.

\subsubsection{Sampling path orientation with respect to the colony}

The two cores extracted from the same colony (08PS-A) allowed us to assess coral $\mathrm{Sr} / \mathrm{Ca}$ reproducibility with respect to the vertical axis of the colony, which is typically assumed to be the maximum growth axis of the colony (i.e., vertical versus horizontal sampling paths) (Fig. 6). We sampled the slab 08PS-A1-C along two paths oriented at $45^{\circ}$ and $70^{\circ}$ from the vertical axis of the colony and we compared these coral $\mathrm{Sr} / \mathrm{Ca}$ records to contemporaneous coral $\mathrm{Sr} / \mathrm{Ca}$ records from 08PS-A2-A and 93DRYSS2 along nearly vertical paths $\left(18^{\circ}\right.$ and $19^{\circ}$ from vertical, respectively). Coral $\mathrm{Sr} / \mathrm{Ca}$ records from the paths at $45^{\circ}$ and $70^{\circ}$ are within analytical precision with those from nearly vertical paths except for two winter extremes in 1854 and 1855 and one summer in 1851 for the path at $70^{\circ}$. There is no evidence for a reduction in annual linear extension for any of the non-vertical paths examined $\left(4.59 \pm 0.72 \mathrm{~mm} \mathrm{year}^{-1}, 1 \sigma\right.$, and $4.05 \pm 0.52$ mm year ${ }^{-1}, 1 \sigma$; for $45^{\circ}$ and $70^{\circ}$, respectively). The discrepancies noted for the path at $70^{\circ}$ do not occur in years with a reduced linear extension, thus the origin of these discrepancies is unknown. 
Similarly, the coral Sr/Ca variations from 93DRYSS2 for the interval from 1778 to 1790 have an orientation of $42^{\circ}$ from vertical (Supplemental Fig. S4) and the record from this path agrees with those from the near vertical paths on 08PS-A2-B (Fig. 8). For S. siderea with extension rates at least $2 \mathrm{~mm}_{\text {year }}{ }^{-1}$ or greater, there is no evidence for a shift to higher $\mathrm{Sr} / \mathrm{Ca}$ values (i.e., colder) for non-vertical sampling paths and we find no difference within analytical precision among horizontal and vertical sampling paths.

The reports of shifts to higher coral $\mathrm{Sr} / \mathrm{Ca}$ and $\delta^{18} \mathrm{O}$ values (i.e., colder) along the sides of columnar coral colonies (McConnaughey, 1989; de Villiers et al., 1994) may simply be the result of reduced growth rates and not sampling path location within the colony. Columnar and branching corals have different extension rates along their longitudinal and radial axes whereas massive corals typically have the same extension rate throughout the colony. Studies with relatively fast-growing (5-20 $\mathrm{mm}_{\text {year }}{ }^{-1}$ ) massive Porites spp. and columnar $P$. clavus suggest a growth-related effect may bias the coral $\mathrm{Sr} / \mathrm{Ca}$ and $\delta^{18} \mathrm{O}$ signal for annual linear extension rates less than 5 mm year ${ }^{-1}$ (McConnaughey, 1989; de Villiers et al., 1994; Felis et al., 2003). However, studies with slower extending coral species (3-6 mm year ${ }^{-1}$ ) like $D$. heliopora and $S$. siderea indicate that coral $\mathrm{Sr} / \mathrm{Ca}$ determinations within and among colonies are reproducible and comparable to faster extending coral species (Porites and Montastraea) in close proximity (Bagnato et al., 2004; DeLong et al., 2011; Dassié and Linsley, 2015). We do not find a mean shift to higher $\mathrm{Sr} / \mathrm{Ca}$ values for years with the slowest extension rates (see section 3.1.3). Our previous study found no consistent relationship between coral Sr/Ca variations and annual linear extension for these corals, and no significant correlation among extension records (DeLong et al., 2014), or between different coral species on the same reef (Muslic et al., 2013), suggesting that coral $\mathrm{Sr} / \mathrm{Ca}$ are not affected by linear extension rates (Supplementary Tables S1 and S2). 


\subsubsection{Diagenesis}

Examination of X-radiographs and scanning electron microscope (SEM) images revealed no evidence of altered primary mineralogy (Supplementary Figs. S2-4) except for the bottom of 08PS-A2-B prior to 1779 (Fig. 7 and Supplementary Fig. S2). X-radiographs of 08PS-A2-B show that the bottom of this core section has a denser skeleton (lighter color in negative images) and evidence of bioerosion (Supplementary Fig. S2). The SEM image from the bottom of 08PSA2-B (Supplementary Fig. S2) contains a transition from pristine skeletal material (top) to secondary aragonite needles in the pore spaces (bottom). Additional SEM images reveal more secondary aragonite infilling towards to bottom of this core (Fig. 7a) as well as evidence of sponge spicules and boring organisms. Coral Sr/Ca determinations from sampling paths adjacent to the SEM sample at the bottom of this slab contain evidence of diagenesis (Fig. 7a). From 79 to $80 \mathrm{~cm}$ in Fig. 7a, the coral Sr/Ca between 08PS-A2-B and 93DRYSS2 do not agree (difference in averages $=0.086 \mathrm{mmol} \mathrm{mol}^{-1}$; equivalent to $2.0^{\circ} \mathrm{C}$ ) yet annual cycles are present but in 08PSA2-B are shifted towards higher values (i.e., colder). Below $80 \mathrm{~cm}$, contemporaneous paths from 08PS-A2-B do not agree and the expected annual cycles are not present with shifts to relatively higher values $\left(>9.1 \mathrm{mmol} \mathrm{mol}^{-1}\right)$ and then to anomalously low values below $82.5 \mathrm{~cm}(<8.732$ mmol $\mathrm{mol}^{-1}$, the minimal value from all cores; Table 1). The coral $\mathrm{Mg} / \mathrm{Ca}$ values (an indicator of diagenesis) increase from an average of $4.3 \mathrm{mmol} \mathrm{mol}^{-1}$ for this core to $25 \mathrm{mmol} \mathrm{mol}^{-1}$ for the bottom of 08PS-A2-B.

The top of 08PS-A2-A was dead with some evidence of bioerosion (Supplementary Fig. S2). Visual analysis of SEM images from a sample from the near the top of this core (Supplementary Fig. S2) revealed no evidence of secondary aragonite. However, our initial sampling path ( 4 years long) penetrated a portion of the coral dissolved by bioerosion that 
produced anomalously low Sr/Ca values $\left(8.7-8.8 \mathrm{mmol} \mathrm{mol}^{-1}\right)$ and loss of annual coral $\mathrm{Sr} / \mathrm{Ca}$ cycles (Fig. 7b). We selected a new path with intact skeletal material expecting some disagreement in the coral $\mathrm{Sr} / \mathrm{Ca}$ determinations among cores due to the bioerosion and dissolution. Coral Sr/Ca values from the new path yielded the expected values and differences were within analytical precision for contemporaneous coral Sr/Ca determinations from our new path with those from 08PS-F1 and 08PS-A1 (1955-1967; Fig. 7a).

The shift to relatively higher $\mathrm{Sr} / \mathrm{Ca}$ values (i.e., lower SST) is consistent with the presence of secondary aragonite and dissolution (Quinn and Taylor, 2006; Hendy et al., 2007; Sayani et al., 2011). Conversely, a shift to relatively lower Sr/Ca values (i.e., higher SST) is consistent with calcite or other cements infilling (McGregor and Gagan, 2003). Sampling paths with evidence of diagenesis from 08PS-A2 are not included in our reproducibility assessment or the final SST reconstruction (DeLong et al., 2014).

\subsection{Reproducibility}

We assessed reproducibility in coral $\mathrm{Sr} / \mathrm{Ca}, \delta^{18} \mathrm{O}$, and $\delta^{13} \mathrm{C}$ for optimally sampled paths using RMS, AD (Eqs. 1 and 2), and correlation ( $r$ ) on various spatial scales from intracolony to $11.5 \mathrm{~km}$ apart and time scales from interannual to decadal. Each core spans a different time interval (Table 1) so comparisons (RMS, AD, and $r$ ) were determined for contemporaneous intervals (Tables 2 and 3). Reproducibility of coral $\mathrm{Sr} / \mathrm{Ca}$ variations among cores was summarized in the SST reconstruction report (DeLong et al., 2014) whereas intracolony reproducibility is presented here as it pertains to coral sampling artifacts. In general, $98.9 \%$ of the coral Sr/Ca variations for optimally sampled coral colonies (08PS-A, 08PS-F1, and 
93DRYSS2) are within analytical precision $(2 \sigma)^{2}$ after smoothing to 36 months to reduce subannual dating uncertainties related to assigning any single coral $\mathrm{Sr} / \mathrm{Ca}$ determination to a calendar month (DeLong et al., 2014) (Fig. 8). These colonies are $510 \mathrm{~m}$ to $11.5 \mathrm{~km}$ apart in shallow water depth (4.3 m for 08PS-A and $3.4 \mathrm{~m}$ for 08PS-F1) and unknown water depth for 93DRYSS2, suggesting that coral $\mathrm{Sr} / \mathrm{Ca}$ variations in S. siderea colonies growing under similar conditions are reproducible. Correlations among annual extension records for these corals vary from positive to negative and coral $\mathrm{Sr} / \mathrm{Ca}$ is not significantly correlated to annual extension (Fig. 8c and Supplementary Table S1) (DeLong et al., 2014), suggesting extension rates are not influencing coral $\mathrm{Sr} / \mathrm{Ca}$ and that annual extension records in S. siderea are not reproducible among colonies, and therefore are not reliable proxies for SST (Supplementary Table S2) (see discussion in DeLong et al., 2014). Furthermore, extension records in S. siderea, M. faveolata, and Diploria strigosa colonies at our study site reveal differing trends and variations among colonies living in the same environmental conditions (Muslic et al., 2013) suggesting biological variable is driving extension rates and not environmental forcing.

We assessed reproducibility for optimally sampled paths on the centimeter scale within a coral colony (i.e., intracolony) between opposing sides of the same slab 08PS-F1 ( $\sim \mathrm{mm}$ apart), between two slabs from the same core 08PS-A1 ( 10 mm apart), and between two cores from the same colony, 08PS-A1 and 08PS-A2 ( 330 mm apart; Table 2). The means and standard deviations of the monthly coral Sr/Ca determinations are not significantly different and correlations are high and significant for all of these intracolony comparisons (Tables 1 and 2). The average AD and RMS of the coral Sr/Ca variations are less than or within $2 \sigma$ of our

${ }^{2}$ Geochemical determinations are not exact values but an average for which the true value may occur anywhere with the analytical precision. The $95 \%$ confidence interval for these determinations is $2 \sigma$ of the analytical precision or the true value follows a Gaussian distribution with a mean (the determined value) and the standard deviation as the analytical precision. 
analytical precisions $\left(0.024\right.$ to $\left.0.039 \mathrm{mmol} \mathrm{mol}^{-1}, 2 \sigma\right)$ for all time scales with the lowest average $\mathrm{AD}$ and RMS for the two comparisons in closest proximity. For individual monthly coral $\mathrm{Sr} / \mathrm{Ca}$ determinations, $10 \%$ to $14 \%$ of the RMS values are greater than $0.026 \mathrm{mmol} \mathrm{mol}^{-1}(2 \sigma$ of average IGS analytical precision) for 08PS-F1 and 08PS-A1; respectively and 28\% of the RMS values determined between 08PS-A1 and 08PS-A2. This percentage decreases to zero after low pass filtering to 36 months (Table 2). This suggests that most of the discrepancies are due to subannual dating uncertainties from assigning any one particular coral $\mathrm{Sr} / \mathrm{Ca}$ determination to a calendar month.

We note that the mean coral Sr/Ca for 08PS-F1 is greater than the 08PS-A $(0.030 \mathrm{mmol}$ $\mathrm{mol}^{-1}$ difference in means determined for $1896-2008$; equivalent to $0.7^{\circ} \mathrm{C}$ ) and some intervals have differences greater than $2 \sigma$ of our analytical precisions (e.g., 1901-1902, 1944-1948, and 1952-1953 in Figure 8). However, there is no consistent mean shift towards greater or lesser values between 08PS-F1 and the other cores, and most intervals agree within analytical precision. We sampled additional paths on the same side of the slab as the original path on 08PSF1 for the interval from 1898 to 1942 in order to confirm these variations and found the average $\mathrm{AD}$ of coral $\mathrm{Sr} / \mathrm{Ca}$ variations between original and new paths $\left(0.027 \pm 0.020 \mathrm{mmol} \mathrm{mol}^{-1}, 1 \sigma\right)$ and the average RMS $\left(0.019 \pm 0.014 \mathrm{mmol} \mathrm{mol}^{-1}, 1 \sigma\right)$ are higher than that observed for the opposing sides of 08PS-F1 for the interval from 1994 to 2009. Another possible explanation is that the interval from 1896 to 1942 is close to the apparent year of initial growth ( 1875) for the colony 08PS-F1 (Supplementary Fig. S3). Little is known about ontogenic effects and coral geochemistry; however, ontogenic shifts have been suggested for massive Porites spp. for corals less than 25 years old (Marshall and McCulloch, 2002; Ourbak et al., 2008). We found no evidence of sampling artifacts that could explain these discrepancies (section 3.1); however, 
researchers with various levels of experience sampled these paths, so these differences may be related to skill level or ontogenic effects.

We assessed reproducibility for monthly-resolved coral $\delta^{18} \mathrm{O}$ and $\delta^{13} \mathrm{C}$ variations from two coral colonies as well as bimonthly-resolved coral $\delta^{18} \mathrm{O}$ variations from 93DRYSS1 (Maupin et al., 2008) (Fig. 5 and Table 3). Coral $\delta^{13} \mathrm{C}$ in 08PS-F1 has a larger annual cycle, means between 08PS-F1 and 08PS-A1 are significantly different, and coral $\delta^{13} \mathrm{C}$ is not reproducible within analytical precision, suggesting that colony-specific biological processes and not environmental factors are driving carbon $\delta^{13} \mathrm{C}$ for the short interval examined. A study with multiple P. lutea corals found similar results for coral $\delta^{13} \mathrm{C}$ (Stephans et al., 2004). Monthly coral $\delta^{18} \mathrm{O}$ are reproducible (average $\mathrm{RMS}=0.07 \pm 0.06,1 \sigma$, and average $\mathrm{AD}=0.10 \pm 0.09,1 \sigma$ ) and differences are within analytical precision $(2 \sigma)$ between these colonies. Discrepancies for coral $\delta^{18} \mathrm{O}$ between bimonthly 93DRYSS1 and monthly 08PS-A1 are greater and this reduced reproducibility may be due to differences in sampling resolution (see section 3.1.3). Similar differences for sampling resolution were found for coral $\mathrm{Sr} / \mathrm{Ca}$ for these coral colonies and for coral Sr/Ca and $\delta^{18} \mathrm{O}$ in same $P$. lutea colony (DeLong et al., 2007). These results for coral $\delta^{18} \mathrm{O}$, despite the short interval for comparison, suggest this proxy is reproducible in S. siderea thus providing support for using coral $\delta^{18} \mathrm{O}$ to develop reconstructions of SST and possibly salinity.

\section{Conclusions}

In this study, we identified sources of sampling artifacts and suggest ways to improve the sampling of S. siderea for the reconstruction of SST using coral Sr/Ca, and by extension to other proxies as well. We find monthly-resolved coral $\mathrm{Sr} / \mathrm{Ca}$ and $\delta^{18} \mathrm{O}$ determinations are reproducible within analytical precision whereas coral $\delta^{13} \mathrm{C}$ is not, suggesting biological processes influencing coral $\delta^{13} \mathrm{C}$ at least on interannual time scales. The largest source of error in monthly coral $\mathrm{Sr} / \mathrm{Ca}$ 
time series is subannual dating uncertainties from assigning a coral $\mathrm{Sr} / \mathrm{Ca}$ value to a particular month. Consistent sampling along the corallite wall is need to avoid cold bias that can be subtle and reduce annual cycles as much as $20 \%$ when sampling within the columella. Diagenesis can also produce subtle shifts in coral $\mathrm{Sr} / \mathrm{Ca}$ that still exhibit a annual cycle but shifted to higher (colder) coral Sr/Ca values. For these corals, sampling resolutions of 6 samples year $^{-1}$ may not recover coral $\mathrm{Sr} / \mathrm{Ca}$ and $\delta^{18} \mathrm{O}$ seasonal extremes and reduce the amplitude for seasonal cycles, which would be problematic for reconstructions of seasonal and interannual variability such as El Niño Southern Oscillation. There is no difference in coral Sr/Ca among sample path orientations with respect to the $S$. siderea colony (i.e., horizontal versus vertical) suggesting microatolls and subfossil corals of $S$. siderea with unknown growth orientation can be used for reconstructions. For these $S$. siderea colonies, extension rates can vary as slow as $2.1 \mathrm{~mm} \mathrm{year}^{-1}$ with no shift to higher (i.e., colder) coral Sr/Ca values related to growth-related or kinetic effects. Coral $\mathrm{Sr} / \mathrm{Ca}$ and $\delta^{18} \mathrm{O}$ variations extracted from multiple $S$. siderea colonies located up to 11.5 $\mathrm{km}$ apart and sampled by multiple workers with similar training display remarkable reproducibility thus, supporting the use of this coral species for developing coral $\mathrm{Sr} / \mathrm{Ca}$ and $\delta^{18} \mathrm{O}$ reconstructions from live and dead corals.

\subsection{Sampling suggestions}

- Sampling S. siderea for geochemical analysis should avoid the less dense columella in the center of the corallite. The optimal sample path location for S. siderea is along the synapticulothecal corallite wall. Cores from S. siderea colonies should be slabbed so that the corallite walls are transected in a longitudinal cross-section with the walls parallel to the slab surface.

- Monitor annual extension and amplitude of geochemical seasonal cycles in S. siderea as 
possible indicators of sampling resolution artifacts or possible growth-related shifts.

- Monthly sampling resolution is preferred to bimonthly resolution for analysis of seasonality in S. siderea and to obtain the full annual SST cycle. We suggest increasing sampling interval for years with $\leq 50 \%$ reduction in annual extension to avoid a reduction in annual cycle introduced by dampening the seasonal variability as longer time intervals are integrated within each sample.

- Sample path orientation with respect to the S. siderea colony can vary from vertical to horizontal for coral $\mathrm{Sr} / \mathrm{Ca}$ determinations.

\section{Acknowledgements}

We acknowledge financial support provided by the Louisiana State University Council on Research Summer Stipend Program and Louisiana Experimental Program to Stimulate Competitive Research (EPSCoR), funded by the National Science Foundation and Board of Regents Support Fund Grant \# LEQSF(2011)-PFUND-229. ${ }^{230}$ Th dating at the HISPEC was supported by the ROC MOST and NTU grants (104-2119-M-002-003, 105-2119-M-002-001 and 105R7625 to CCS). We thank Chris Reich, Don Hickey, Jordan Sanford, B.J. Reynolds, Michèle LaVigne, the M/V Fort Jefferson crew, and Dry Tortugas National Park personnel for their support in recovery of coral cores under scientific research permit DRTO-2008-SCI-0015. Kelly Hereid, Liz Powell, Meaghan Gorman, and Dorinda Ostermann of UT are acknowledged for their analytical assistance. We thank Mary Manheim and Ginny Listi of the LSU FACES laboratory for their assistance with X-raying the corals, Alexandra Beard, Anna La Valley and Robin Cobb of LSU PAST laboratory for their sampling assistance, and Mary Lee Eggart formally of LSU for creating the coral artwork. DeLong thanks Nanyang Technical University and Nathalie Goodkin for their support during her sabbitcal. Lastly, we thank Dick Poore, Robert 
Halley, and Gene Shinn, formally of the USGS, for their vast knowledge and expertise. Any use of trade names is for descriptive purposes only and does not imply endorsement by the U.S.

Government. The coral Sr/Ca data are archived at the World Data Center for Paleoclimatology www.ncdc.noaa.gov/paleo, 325 Broadway, Boulder, Colorado; IGBP PAGES/World Data Center for Paleoclimatology Data Contribution Series \#noaa-coral-16217, ftp://ftp.ncdc.noaa.gov/pub/data/paleo/coral/atlantic/delong2014/.

\section{References}

Alibert, C., McCulloch, M.T., 1997. Strontium/calcium ratios in modern Porites corals from the Great Barrier Reef as a proxy for sea surface temperature: Calibration of the thermometer and monitoring of ENSO. Paleoceanography 12, 345-363, doi:10.1029/97PA00318.

Bagnato, S., Linsley, B.K., Howe, S.S., Wellington, G.M., Salinger, J., 2004. Evaluating the use of the massive coral Diploastrea heliopora for paleoclimate reconstruction.

Paleoceanography 19, PA1032, doi:10.1029/2003PA000935.

Barnes, D.J., 1973. Growth in colonial Scleractinians. Bulletin of Marine Science 23, 280-298.

Bloomfield, P., 2000. Fourier Analysis of Time Series: An Introduction, Second ed. John Wiley \& Sons, New York.

Bradley, R.S., 2015. Paleoclimatology - Reconstructing Climates of the Quaternary, Third ed. Academic Press, Oxford, UK.

Budd, A.F., Fukami, H., Smith, N.D., Knowlton, N., 2012. Taxonomic classification of the reef coral family Mussidae (Cnidaria: Anthozoa: Scleractinia). Zoological Journal of the Linnean Society 166, 465-529, doi:10.1111/j.1096-3642.2012.00855.x.

Cohen, A.L., Hart, S.R., 1997. The effect of colony topography on climate signals in coral skeleton. Geochimica et Cosmochimica Acta 61, 3905-3912. 
Corrège, T., 2006. Sea surface temperature and salinity reconstruction from coral geochemical tracers. Palaeogeography, Palaeoclimatology, Palaeoecology 232, 408-428, doi:10.1016/j.palaeo.2005.10.014.

Darke, W.M., Barnes, D.J., 1993. Growth trajectories of corallites and ages of polyps in massive colonies of reef-building corals of the genus Porites. Marine Biology 117, 321-326, doi:10.1007/BF00345677.

Dassié, E.P., Linsley, B.K., 2015. Refining the sampling approach for the massive coral Diploastrea heliopora for $\delta^{18} \mathrm{O}$-based paleoclimate applications. Palaeogeography, Palaeoclimatology, Palaeoecology 440, 274-282, doi:10.1016/j.palaeo.2015.08.043.

de Villiers, S., Shen, G.T., Nelson, B.K., 1994. The Sr/Ca-temperature relationship in coralline aragonite: Influence of variability in $(\mathrm{Sr} / \mathrm{Ca})_{\text {seawater }}$ and skeletal growth parameters. Geochimica et Cosmochimica Acta 58, 197-208, doi:10.1016/0016-7037(94)90457-x.

DeLong, K.L., Quinn, T.M., Taylor, F.W., 2007. Reconstructing twentieth-century sea surface temperature variability in the southwest Pacific: A replication study using multiple coral Sr/Ca records from New Caledonia. Paleoceanography 22, PA4212, doi:10.1029/2007PA001444.

DeLong, K.L., Flannery, J.A., Maupin, C.R., Poore, R.Z., Quinn, T.M., 2011. A coral Sr/Ca calibration and replication study of two massive corals from the Gulf of Mexico. Palaeogeography Palaeoclimatology Palaeoecology 307, 117-128, doi:10.1016/j.palaeo.2011.05.005.

DeLong, K.L., Quinn, T.M., Taylor, F.W., Lin, K., Shen, C.-C., 2013. Improving coral-base paleoclimate reconstructions by replicating 350 years of coral $\mathrm{Sr} / \mathrm{Ca}$ variations. Palaeogeography Palaeoclimatology Palaeoecology 373, 6-24, 
doi:10.1016/j.palaeo.2012.08.019.

DeLong, K.L., Flannery, J.A., Poore, R.Z., Quinn, T.M., Maupin, C.R., Lin, K., Shen, C.-C., 2014. A reconstruction of sea surface temperature variability in the southeastern Gulf of Mexico from 1734-2008 C.E. using cross-dated Sr/Ca records from the coral Siderastrea siderea. Paleoceanography 29, 403-422, doi:10.1002/2013PA002524.

Druffel, E.R.M., 1997. Geochemistry of corals: proxies of past ocean chemistry, ocean circulation, and climate. Proceedings of the National Academy of Sciences of the United States of America 94, 8354-8361.

Felis, T., Pätzold, J., Loya, Y., 2003. Mean oxygen-isotope signatures in Porites spp. corals: inter-colony variability and correction for extension-rate effects. Coral Reefs 22, 328336, doi:10.1007/s00338-003-0324-3.

Felis, T., Patzold, J., 2004. Climate reconstructions from annually banded corals, in: Shiyomi, M. (Ed.), Global environmental change in the ocean and on land. Terrapub, Tokyo, pp. 205227.

Felis, T., Suzuki, A., Kuhnert, H., Dima, M., Lohmann, G., Kawahata, H., 2009. Subtropical coral reveals abrupt early-twentieth-century freshening in the western North Pacific Ocean. Geology 37, 527-530, doi:10.1130/g25581a.1.

Gaffey, S.J., Kolak, J.J., E. Bronnimann, C., 1991. Effects of drying, heating, annealing, and roasting on carbonate skeletal material, with geochemical and diagenetic implications. Geochimica et Cosmochimica Acta 55, 1627-1640, doi:10.1016/0016-7037(91)90134-Q.

Gagan, M.K., Ayliffe, L.K., Beck, J.W., Cole, J.E., Druffel, E.R.M., Dunbar, R.B., Schrag, D.P., 2000. New views of tropical paleoclimates from corals. Quaternary Science Reviews 19, $45-64$. 
Giry, C., Felis, T., Kölling, M., Scheffers, S., 2010. Geochemistry and skeletal structure of Diploria strigosa, implications for coral-based climate reconstruction. Palaeogeography, Palaeoclimatology, Palaeoecology 298, 378-387, doi:10.1016/j.palaeo.2010.10.022.

Grottoli, A., Eakin, M., 2007. A review of modern coral $\delta^{18} \mathrm{O}$ and $\Delta^{14} \mathrm{C}$ proxy records. EarthScience Reviews 81, 67-91.

Hendy, E., Gagan, M.K., Lough, J.M., McCulloch, M., deMenocal, P.B., 2007. Impact of skeletal dissolution and secondary aragonite on trace element and isotopic climate proxies in Porites corals. Paleoceanography 22, PA4101, doi:10.1029/2007PA001462.

Hughes, T.P., 1987. Skeletal density and growth form of corals. Marine Ecology - Progress series 35, 259-266.

Jones, P.D., Briffa, K.R., Osborn, T.J., Lough, J.M., van Ommen, T.D., Vinther, B.M., Luterbacher, J., Wahl, E.R., Zwiers, F.W., Mann, M.E., Schmidt, G.A., Ammann, C.M., Buckley, B.M., Cobb, K.M., Esper, J., Goosse, H., Graham, N., Jansen, E., Kiefer, T., Kull, C., Kuttel, M., Mosley-Thompson, E., Overpeck, J.T., Riedwyl, N., Schulz, M., Tudhope, A.W., Villalba, R., Wanner, H., Wolff, E., Xoplaki, E., 2009. High-resolution palaeoclimatology of the last millennium: A review of current status and future prospects. The Holocene 19, 3-49, doi:10.1177/0959683608098952.

Kilbourne, K.H., Quinn, T.M., Taylor, F.W., 2004. A fossil coral perspective on western tropical Pacific climate 350 ka. Paleoceanography 19, PA1019, doi:10.1029/2003PA000944.

Knowlton, N., Budd, A.F., 2001. Recognizing coral species past and present, in: Cheetham, A.H., Jackson, J.B.C., Lidgard, S., McKinney, F.K. (Eds.), Evolutionary Patterns: Growth, Form, and Tempo in the Fossil Record. University of Chicago Press, Chicago, pp. 97-119. 
Knutson, D., Buddemeier, R., Smith, S., 1972. Coral chronometers: Seasonal growth bands in reef corals. Science 177, 270-272, doi:10.1126/science/177.4045.270.

Kuffner, I.B., Hickey, T.D., Morrison, J.M., 2013. Calcification rates of the massive coral Siderastrea siderea and crustose coralline algae along the Florida Keys (USA) outer-reef tract. Coral Reefs 32, 987-997, doi:10.1007/s00338-013-1047-8.

Leder, J.J., Swart, P.K., Szmant, A.M., Dodge, R.E., 1996. The origin of variations in the isotopic record of scleractinian corals: I. Oxygen. Geochimica et Cosmochimica Acta 60, 2857-2870.

Lough, J.M., 2010. Climate records from corals. Wiley Interdisciplinary Reviews: Climate Change 1, 318-331, doi:10.1002/wcc.39.

Maier, C., Felis, T., Patzold, J., Bak, R.P.M., 2004. Effect of skeletal growth and lack of species effects in the skeletal oxygen isotope climate signal within the coral genus Porites. Marine Geology 207, 193-208, doi:10.1016/j.margeo.2004.03.008.

Marshall, J.F., McCulloch, M.T., 2002. An assessment of the $\mathrm{Sr} / \mathrm{Ca}$ ratio in shallow water hermatypic corals as a proxy for sea surface temperature. Geochimica et Cosmochimica Acta 66, 3263-3280, doi:10.1016/5016-7037(20)00926-2.

Maupin, C.R., Quinn, T.M., Halley, R.B., 2008. Extracting a climate signal from the skeletal geochemistry of the Caribbean coral Siderastrea siderea. Geochemistry Geophysics Geosystems 9, Q12012, doi:10.1029/2008GC002106.

McConnaughey, T., 1989. ${ }^{13} \mathrm{C}$ and ${ }^{18} \mathrm{O}$ isotopic disequilibrium in biological carbonates: I. Patterns. Geochimica et Cosmochimica Acta 53, 151-162, doi:10.1016/00167037(89)90282-2. 
McGregor, H.V., Gagan, M.K., 2003. Diagenesis and geochemistry of Porites corals from Papua New Guinea: Implications for paleoclimate reconstruction. Geochim. Cosmochim. Acta $67,2147-2156$.

McGregor, H.V., Fischer, M.J., Gagan, M.K., Fink, D., Woodroffe, C.D., 2011. Environmental control of the oxygen isotope composition of Porites coral microatolls. Geochimica et Cosmochimica Acta 75, 3930-3944, doi:10.1016/j.gca.2011.04.017.

Mitsuguchi, T., Matsumoto, E., Uchida, T., 2003. Mg/Ca and Sr/Ca ratios of Porites coral skeleton: Evaluation of the effect of skeletal growth rate. Coral Reefs 22, 381-388, doi:10.1007/S00338-003-0326-1.

Muslic, A., Flannery, J.A., Reich, C.D., Umberger, D.K., Smoak, J.M., Poore, R.Z., 2013. Linear Extension Rates of Massive Corals from the Dry Tortugas National Park (DRTO), Florida. U.S. Geological Survey Open-File Report 2013-1121.

Ourbak, T., DeLong, K.L., Corrège, T., Malaizé, B., Kilbourne, K.H., Caquineau, S., Hollander, D.J., 2008. The significance of geochemical proxies in corals, does size (age) matter?, International Coral Reef Symposium. Proceedings of the 11th International Coral Reef Symposium, Ft. Lauderdale, Florida, pp. 82-86.

Paillard, D., Labeyrie, L., Yiou, P., 1996. Macintosh program performs time-series analysis. EOS, Transactions American Geophysical Union 77, 379, doi:10.1029/96EO00259.

Quinn, T.M., Taylor, F.W., Crowley, T.J., Link, S.M., 1996. Evaluation of sampling resolution in coral stable isotope records: A case study using records from New Caledonia and Tarawa. Paleoceanography 11, 529-542, doi:10.1029/96PA01859.

Quinn, T.M., Taylor, F.W., 2006. SST artifacts in coral proxy records produced by early marine diagenesis in a modern coral from Rabaul, Papua New Guinea. Geophysical Research 
$8 / 9 / 16$

Letters 33, L04601, doi:10.1029/2005GL024972.

Quinn, T.M., Taylor, F.W., Crowley, T.J., 2006. Coral-based climate variability in the Western Pacific Warm Pool since 1867. Journal of Geophysical Research-Oceans 111, C11006, doi:10.1029/2005JC003243.

Risk, M.J., Sammarco, P.W., 1991. Cross-shelf trends in skeletal density of the massive coral Porites lobata from the Great Barrier Reef. Marine Ecology Progress Series 69, 195-200.

Sadler, J., Webb, G.E., Nothdurft, L.D., Dechnik, B., 2014. Geochemistry-based coral palaeoclimate studies and the potential of 'non-traditional' (non-massive Porites) corals: Recent developments and future progression. Earth-Science Reviews 139, 291-316, doi:10.1016/j.earscirev.2014.10.002.

Sayani, H.R., Cobb, K.M., Cohen, A.L., Elliott, W.C., Nurhati, I.S., Dunbar, R.B., Rose, K.A., Zaunbrecher, L.K., 2011. Effects of diagenesis on paleoclimate reconstructions from modern and young fossil corals. Geochimica et Cosmochimica Acta 75, 6361-6373, doi:10.1016/j.gca.2011.08.026.

Schrag, D.P., 1999. Rapid analysis of high-precision $\mathrm{Sr} / \mathrm{Ca}$ ratios in corals and other marine carbonates. Paleoceanography 14, 97-102, doi:10.1029/1998PA900025.

Shen, C.-C., Li, K.-S., Sieh, K., Natawidjaja, D., Cheng, H., Wang, X., Edwards, R.L., Lam, D.D., Hsieh, Y.-T., Fan, T.-Y., Meltzner, A.J., Taylor, F.W., Quinn, T.M., Chiang, H.W., Kilbourne, K.H., 2008. Variation of initial ${ }^{230} \mathrm{Th} /{ }^{232} \mathrm{Th}$ and limits of high precision U-Th dating of shallow-water corals. Geochimica et Cosmochimica Acta 72, 4201-4223, doi:10.1016/j.gca.2008.06.011.

Shen, C.-C., Wu, C.-C., Cheng, H., Lawrence Edwards, R., Hsieh, Y.-T., Gallet, S., Chang, C.C., Li, T.-Y., Lam, D.D., Kano, A., Hori, M., Spötl, C., 2012. High-precision and high- 
resolution carbonate ${ }^{230} \mathrm{Th}$ dating by MC-ICP-MS with SEM protocols. Geochimica et Cosmochimica Acta 99, 71-86, doi:10.1016/j.gca.2012.09.018.

Smith, J.M., Quinn, T.M., Helmle, K.P., Halley, R.B., 2006. Reproducibility of geochemical and climatic signals in the Atlantic coral Montastraea faveolata. Paleoceanography 21, PA1010, doi:10.1029/2005PA001187.

Stephans, C., Quinn, T.M., Taylor, F.W., Corrège, T., 2004. Assessing the reproducibility of coral-based climate records. Geophysical Research Letters 31, L18210, doi:10.1029/2004GL020343.

Swart, P.K., Elderfield, H., Greaves, M.J., 2002. A high-resolution calibration of $\mathrm{Sr} / \mathrm{Ca}$ thermometry using the Caribbean coral Montastraea annularis. Geochemistry Geophysics Geosystems 3, 8402, doi:10.1029/2002GC000306.

Veron, J.E.N., 1986. Corals of Australia and the Indo-Pacific, Univeristy of Hawaii Press edition ed. Univeristy of Hawaii Press edition, North Ryde, NSW, Australia.

Veron, J.E.N., 1995. Corals in Space and Time, The Biogeography and Evolution of the Scleractinia. Comstock/Cornell, Ithaca and London.

Veron, J.E.N., 2000. Corals of the World. Australian Institute of Marine Science and CRR Qld Pty Ltd., Townsville, AUS.

Waite, A.J., Swart, P.K., 2015. The inversion of aragonite to calcite during the sampling of skeletal archives: Implications for proxy interpretation. Rapid Communications in Mass Spectrometry 29, 955-964, doi:10.1002/rcm.7180.

Watanabe, T., Gagan, M.K., Corrège, T., Scott-Gagan, H., Cowley, J., Hantoro, W.S., 2003. Oxygen isotope systematics in Diploastrea heliopora: New coral archive of tropical paleoclimate. Geochimica et Cosmochimica Acta 67, 1349-1358. 
Woodroffe, C.D., and M. K. Gagan, 2000. Coral microatolls from the central Pacific record late Holocene El Niño. Geophysical Research Letters 27, 1511-1514.

Wu, H.C., Linsley, B.K., Dassié, E.P., Schiraldi, B., deMenocal, P.B., 2013. Oceanographic variability in the South Pacific Convergence Zone region over the last 210 years from multi-site coral Sr/Ca records. Geochemistry, Geophysics, Geosystems 14, 1435-1453, doi:10.1029/2012GC004293.

Zinke, J., Reuning, L., Pfeiffer, M., Wassenburg, J., Hardman, E., Jhangeer-Khan, R., Davies, G.R., Ng, C.K.C., Kroon, D., 2016. A sea surface temperature reconstruction for the southern Indian Ocean trade wind belt from corals in Rodrigues Island $\left(19^{\circ} \mathrm{S}, 63^{\circ} \mathrm{E}\right)$. Biogeosciences Discuss. 2016, 1-58, doi:10.5194/bg-2016-69.

\section{Figures Captions}

Fig. 1 Example of improper (left) and proper (right) slabs of a coral core for geochemical analysis. 08PS-A1-A slab 1 on the left has oblong top of corallites visible on the slab surface (inset) and the X-radiograph has a wavy appearance without clear annual density bands compared to the X-radiograph on the right, which has optimal alignment of corallites. Slab on the right (08PS-A1-A slab 3) is a quarter section of the core taken at $90^{\circ}$ from 08PS-A1-A slab 1 and the synapticulothecal corallite walls are parallel to the surface.

Fig. 2 Coral $\mathrm{Sr} / \mathrm{Ca}$ variations across corallites of S. siderea. (A) Samples were extracted from the coral slab 08PS-A2-A for the year 1950 (see Supplementary Fig. S2 for location). (B) Xradiograph of the coral with sampling paths superimposed. (c) Coral scan enlarged by $1000 \%$ with coral Sr/Ca variations superimposed by sample number (\#) and aligned to respective sampling path to $\sim 1 \mathrm{~mm}$. The central spongy columella (C) occurs in the center of the corallite and thick synapticulothecal corallite walls (W) are on either side. Sr/Ca axis is reversed so that 
warm values are up. Errors bars are $2 \sigma$ analytical precision.

Fig. 3 Coral Sr/Ca variations along different portions of a S. siderea corallite in 08PS-F1 (see Supplementary Fig. S3 for location). (A) Scan of coral shown in (B) before sampling with corallite walls and columella labeled. (C) Coral Sr/Ca variations along the sampling lines in (B) and with two sampling paths (see Supplementary Fig. S3 for location) used in the SST reconstruction (DeLong et al., 2014). (D) Drawing of S. siderea in cross section along the growth axis with central spongy columella and thick synapticulothecal corallite walls, which are the optimal sample path locations. (E) Example of a problematic sampling interval (gray area) in the columella from 08PS-A2-B (see Supplementary Fig. S2 for location). Sr/Ca axes are reversed so that warm values are up and are scaled to the same interval. Errors bars are $2 \sigma$ analytical precision.

Fig. 4 Sampling resolution and extension rate assessment. (A) Sampling resolution comparison among coral Sr/Ca variations with resolution of $\sim 12$ samples year ${ }^{-1}$ (08PS-A1 and 08PS-F1; this study and DeLong et al., 2014) and 6 samples year ${ }^{-1}$ (93DRYSS1; (Maupin et al., 2008) for a select interval. (B) Contemporary coral $\mathrm{Sr} / \mathrm{Ca}$ variations from two colonies with boxes enclosing years with slower extension $(<2.6 \mathrm{~mm})$ with extension given for each year. One year $(1783$; black box) had slower extension in both cores. $\mathrm{Sr} / \mathrm{Ca}$ axes are reversed so that warm values are up and are scaled to the same interval. Errors bars are $2 \sigma$ analytical precision.

Fig. 5 Comparison of coral (A) $\delta^{18} \mathrm{O}$ and (B) $\delta^{13} \mathrm{C}$ variations among colonies. Sampling resolution is $\sim 12$ samples year $^{-1}$ for 08PS-A1 and 08PS-F1 (this study and DeLong et al., 2014) and $\sim 6$ samples year $^{-1}$ for 93DRYSS1 (Maupin et al., 2008). Isotopic axes are reversed. Errors bars are $2 \sigma$ analytical precision.

Fig. 6 Comparison of coral Sr/Ca variations with respect to colony orientation. (A) Two cores 
were extracted from a large $S$. siderea colony (08PS-A) that has a flat top, (B) one in the center with a dead top (08PS-A2) and one offset from center with a live top (08PS-A1). (C) Xradiographs of slabs extracted from 08PS-A; labels as in Supplementary Fig. S2, with slabs visually aligned since density variations are continuous between cores. Note: secondary density patterns 8 to 12 years that span the colony. Growth direction of 08PS-A1 changes to almost horizontal towards the bottom of the core. (D) Contemporaneous coral $\mathrm{Sr} / \mathrm{Ca}$ variations compared among the three paths in 08PS-A with different growth orientations with respect to the vertical axis of the colony and with variations from 93DRYSS2 that has a sampling orientation of $19^{\circ}$ from vertical (Supplementary Fig. S4). Sr/Ca axis is reversed so that warm values are up. Errors bars are $2 \sigma$ analytical precision.

Fig. 7 Comparison among sampling paths that have evidence of diagenesis. (A) Coral $\mathrm{Sr} / \mathrm{Ca}$ variations from the bottom section of the slab 08PS-A2-B (1778 to bottom of core; Supplementary Fig. S2). SEM image reveals the presence of secondary aragonite (inset; scale bar $=200 \mu \mathrm{m})$. (B) Coral Sr/Ca variations from the top section of the slab 08PS-A2-A that was dead (Supplementary Fig. S2). One path in 08PS-A2-A through a region with altered skeleton is compared to a second path from the same slab and other coral colonies. Sr/Ca axes are reversed so that warm values are up. Error bars are analytical precision $(2 \sigma)$.

Fig. 8 Interannual coral Sr/Ca reproducibility. (A) Number (\#) of cores sampled for each month. (B) Monthly coral Sr/Ca determinations smoothed with a 36-month LPFIR filter (90\% pass = 62.5 months) (Bloomfield, 2000) to minimize subannual dating uncertainties and highlight variability greater than seasonal. The range of possible values is shown in shaded areas representing analytical precision $\left( \pm 0.024 \mathrm{mmol} \mathrm{mol}^{-1} 1,2 \sigma\right)$ and error bars showing analytical for IGS and PL coral standard ( \pm 0.026 to $0.039 \mathrm{mmol} \mathrm{mol}^{-1}, 2 \sigma$; black and red respectively). Areas 
where shaded colors overlap are not different within analytical precision $\left( \pm 0.024 \mathrm{mmol} \mathrm{mol}^{-1}\right.$, $2 \sigma$ ). Coral $\mathrm{Sr} / \mathrm{Ca}$ axis is reversed so that warm values are up. (C) Annual linear extension (Ext.) determined between Sr/Ca maxima (February to February). (D) Absolute differences (AD) for any single month in (B) with gray dashed line denoting the average $\mathrm{AD}\left(0.010 \mathrm{mmol} \mathrm{mol}{ }^{-1}\right)$ and black dashed line is analytical error $\left(0.026 \mathrm{mmol} \mathrm{mol}^{-1}, 2 \sigma\right)$. 
Table 1 Summary of monthly-resolved coral $\mathrm{Sr} / \mathrm{Ca}$ variations.

\begin{tabular}{llllll}
\hline Statistic & 08PS-A1 & 08PS-A2 & 08PS-F1 & 93DRYSS2 & 93DRYSS1 ${ }^{\mathrm{a}}$ \\
\hline Mean & 8.990 & 9.015 & 9.017 & 9.019 & 8.999 \\
Median & 8.981 & 9.012 & 9.017 & 9.016 & 9.001 \\
Std. deviation & 0.124 & 0.121 & 0.123 & 0.118 & 0.103 \\
Maximum & 9.314 & 9.378 & 9.338 & 9.367 & 9.255 \\
Minimum & 8.732 & 8.734 & 8.740 & 8.747 & 8.792 \\
Seasonal $^{\mathrm{b}}$ & $0.356( \pm 0.051)$ & $0.349( \pm 0.065)$ & $0.366( \pm 0.052)$ & $0.352( \pm 0.056)$ & $0.266( \pm 0.046)$ \\
Extension $^{\mathrm{c}}$ & $4.82( \pm 0.59)$ & $4.01( \pm 0.69)$ & $3.83( \pm 0.53)$ & $3.93( \pm 0.66)$ & $4.94( \pm 0.73)$ \\
$n^{\mathrm{d}}$ & 765 & 2266 & 1342 & 2048 & 561 \\
Years $_{\text {Sampling }}{ }^{\mathrm{e}}$ & $1945-2008$ & $1779-1967$ & $1896-2008$ & $1733-1904$ & $1990-1993$ \\
\hline
\end{tabular}

Determined in the time domain. Units are $\mathrm{mmol} \mathrm{mol}^{-1}$ unless otherwise indicated.

${ }^{a}$ Core from previous study of Maupin et al. (2008).

${ }^{\mathrm{b}}$ Average seasonal cycle $( \pm 1 \sigma)$ determined between winter maxima (February) in $\mathrm{Sr} / \mathrm{Ca}$ for each year.

${ }^{c}$ Average extension $( \pm 1 \sigma)$ determined between winter maxima (February) in $\mathrm{Sr} / \mathrm{Ca}$ for each year. Units are mm year ${ }^{-1}$.

${ }^{\mathrm{d}}$ Number of observations $(n)$.

${ }^{\text {e }}$ Sampling interval is $\mathrm{mm}$ sample $^{-1}$. 
Table 2 Reproducibility statistics for coral $\mathrm{Sr} / \mathrm{Ca}$.

\begin{tabular}{|c|c|c|c|c|c|c|c|c|c|c|c|c|c|c|}
\hline \multirow{5}{*}{$\begin{array}{l}\text { Years }^{\mathrm{a}} \\
\text { Water depth } \\
\text { Distance } \\
\text { Statistic }^{\mathrm{b}}\end{array}$} & \multicolumn{3}{|c|}{$\begin{array}{c}\text { Opposing sides of } \\
\text { same slab } \\
\text { 08PS-F1 }\end{array}$} & \multicolumn{3}{|c|}{$\begin{array}{c}\text { Two slabs, same } \\
\text { colony } \\
\text { 08PS-A1 } \\
\text { slabs } 2 \text { and } 3\end{array}$} & \multicolumn{3}{|c|}{$\begin{array}{c}\text { Two cores, same } \\
\text { colony } \\
\text { 08PS-A1 and } \\
\text { 08PS-A2 }\end{array}$} & \multicolumn{3}{|c|}{$\begin{array}{l}\text { Two colonies, in } \\
\text { close proximity } \\
\text { 08PS-A and } \\
\text { 08PS-F1 }\end{array}$} & \multicolumn{2}{|c|}{$\begin{array}{l}\text { Two colonies, } \\
\text { same reef } \\
\text { 08PS-A and } \\
\text { 93DRYSS2 }\end{array}$} \\
\hline & \multicolumn{3}{|c|}{ 1994-2008 (146) } & \multicolumn{3}{|c|}{ 1984-2008 (287) } & \multicolumn{3}{|c|}{ 1945-1967 (276) } & \multicolumn{3}{|c|}{$1896-1967$ (857) } & \multicolumn{2}{|c|}{$1779-1904(150$} \\
\hline & \multicolumn{3}{|c|}{$3.4 \mathrm{~m}$} & \multicolumn{3}{|c|}{$4.3 \mathrm{~m}$} & \multicolumn{3}{|c|}{$4.3 \mathrm{~m}$} & \multicolumn{3}{|c|}{3.4 and $4.5 \mathrm{~m}$} & \multicolumn{2}{|c|}{$4.3 \mathrm{~m}$ and? } \\
\hline & & $5 \mathrm{~mm}$ & & & $10 \mathrm{mr}$ & & & & & & & & & \\
\hline & & $\mathrm{AD}$ & & & $\mathrm{AD}$ & $r$ & & & & MS & & & $\mathrm{S}$ & $r$ \\
\hline & & & & & & & & & & & & & & \\
\hline & & & & & & & & & & & & & & \\
\hline & & & & & & & & & & & & & & \\
\hline & & & & & & & & & & & & & & 0.3 \\
\hline & & 0. & & & & & & & & & & & & 0.32 \\
\hline 0 years & $\sqrt{A}$ & NA & NA & 0.003 & 0.00 & 0.53 & 0.012 & 0.016 & 0.57 & 0.01 & 0.022 & 0.43 & 0.0100 .014 & 0.19 \\
\hline
\end{tabular}

NA is not applicable.

${ }^{a}$ Years of the common interval with number of pairs used in determinations in parentheses.

${ }^{\mathrm{b}} \mathrm{RMS}$ is the average RMS (Eq. 1) and AD is the average AD (Eq. 2) for all common years; units are $\mathrm{mmol} \mathrm{mol}^{-1}$. Pearson correlation coefficient $(r)$ for all common years; all correlations are significant $(p \leq 0.05)$ and assessed with df.

${ }^{c}$ Monthly anomalies are calculated with respect to the interval from 1971 to 1990.

${ }^{\mathrm{d}}$ Monthly anomalies are smoothed with LPFIR filter (Bloomfield, 2000) with $90 \%$ pass $=11$ months for 7 months, 62.5 months for 36 months, and 16.7 years for 10 years.

${ }^{\text {e }}$ Mean annual (MA) values are calculated for February to January (winter maxima in coral $\mathrm{Sr} / \mathrm{Ca})$. 
Table 3 Reproducibility statistics for coral $\delta^{18} \mathrm{O}$ and $\delta^{13} \mathrm{C}$.

\begin{tabular}{lcccccc}
\hline & \multicolumn{2}{c}{ 08PS-A1 and 08PS-F1 } & \multicolumn{3}{c}{ 08PS-A1 and 93DRYSS1 } \\
Years $^{\mathrm{a}}$ & \multicolumn{2}{c}{ 2001-2007 (67) } & RMS & AD & $r$ \\
Statistic $^{\mathrm{b}}$ & RMS & AD & $r$ & NA & NA & NA \\
\hline Monthly $\delta^{18} \mathrm{O} 0.07$ & 0.10 & 0.89 & Bimonthly $\delta^{18} \mathrm{O} 0.13$ & 0.18 & 0.71 \\
\hline Monthly $\delta^{13} \mathrm{C} 0.20$ & 0.28 & 0.70 & NA & & &
\end{tabular}

NA is not applicable.

${ }^{a}$ Years of the common interval with number of pairs used in determinations in parentheses.

${ }^{b}$ RMS is the average RMS (Eq. 1) and AD is the average AD (Eq. 2) for all common years; units are $\mathrm{mmol} \mathrm{mol}{ }^{-1}$. Pearson correlation coefficient $(r)$ for all common years; all correlations are significant $(p \leq 0.05)$ and assessed with df.

c $08 \mathrm{PS}-\mathrm{A} 1$ averaged to bimonthly intervals similar to 93DRYSS1. 
Suboptimal slab

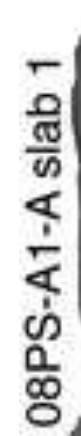

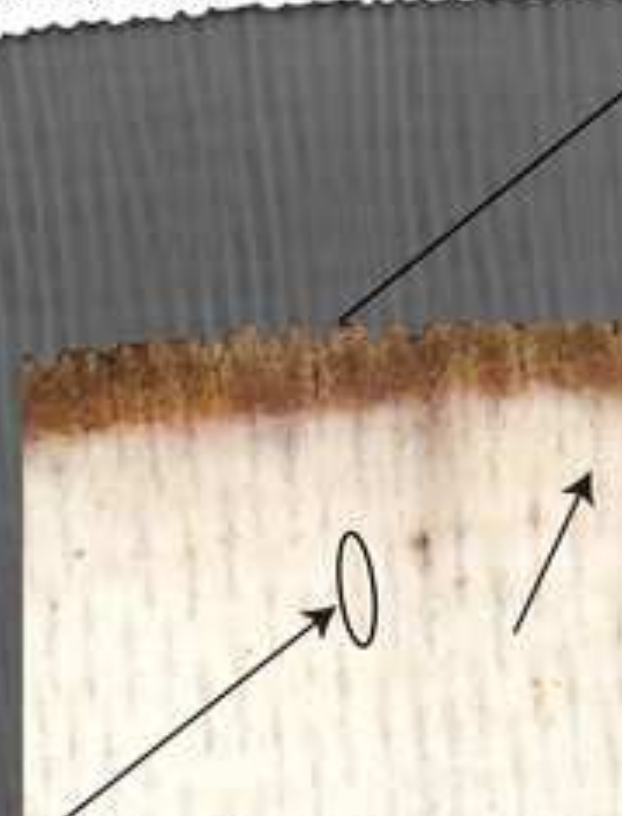

Oblong cross section of the top of the corallites seen on slab surface; suboptimal corallite alignment with respect to slab surface.

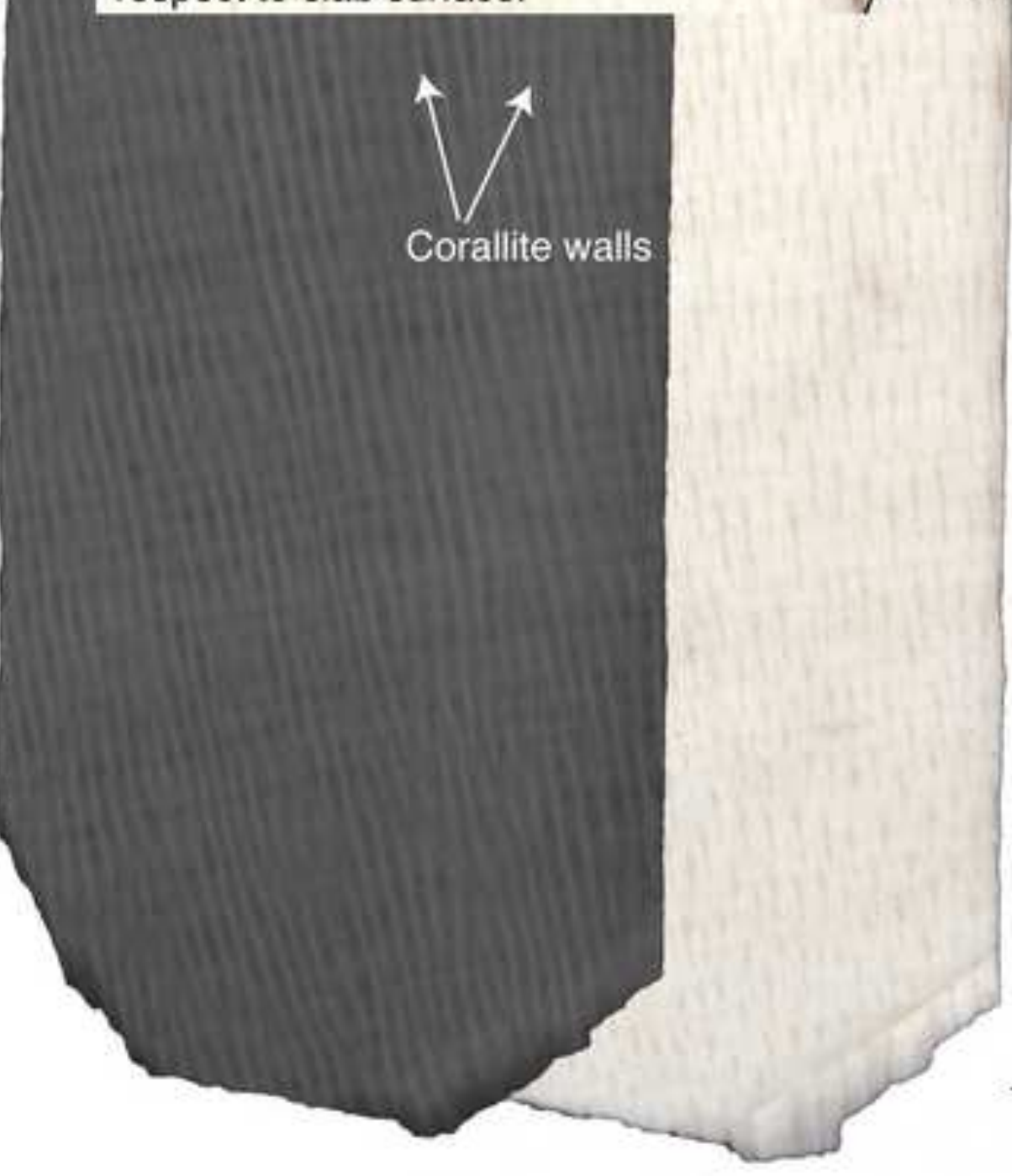

Optimal slab

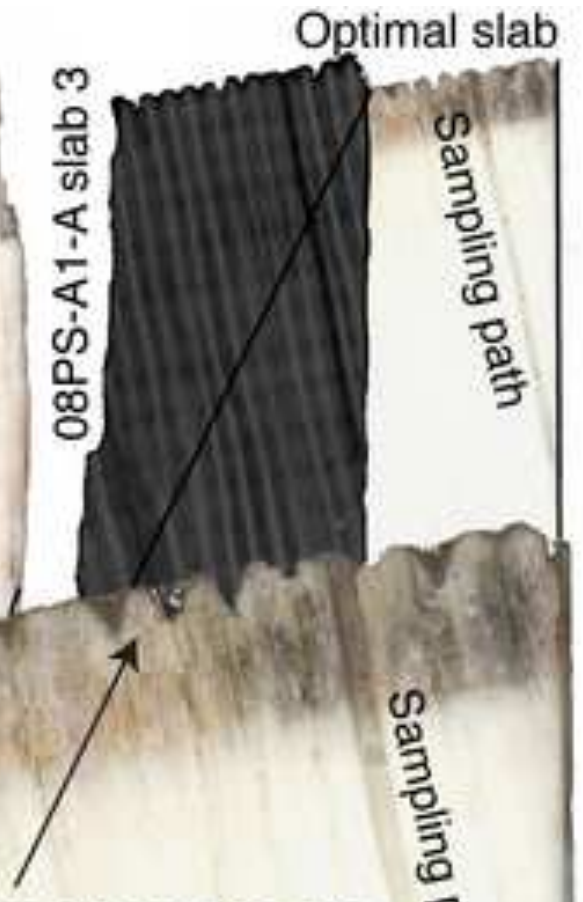

Top of corallite with synapticulothecal walls parallel to slab surface.
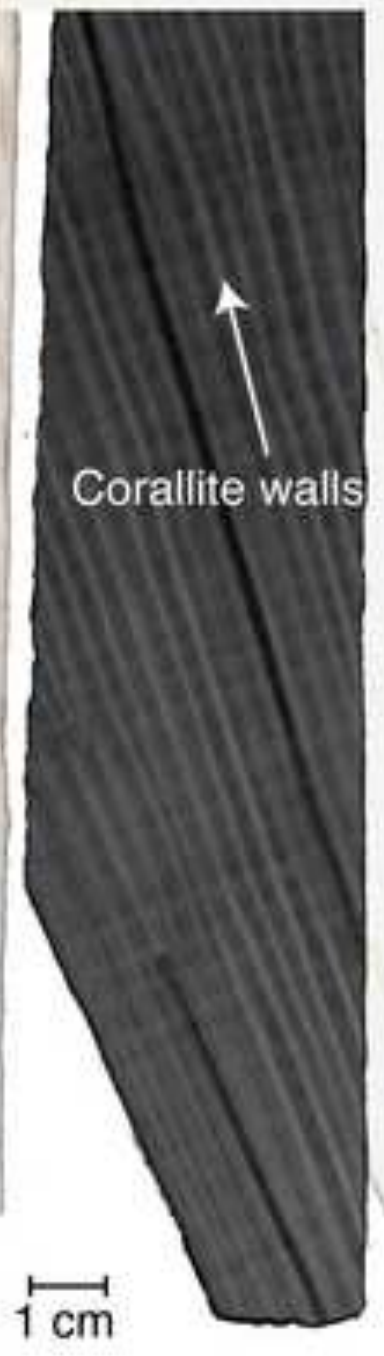
A

Sample
paths

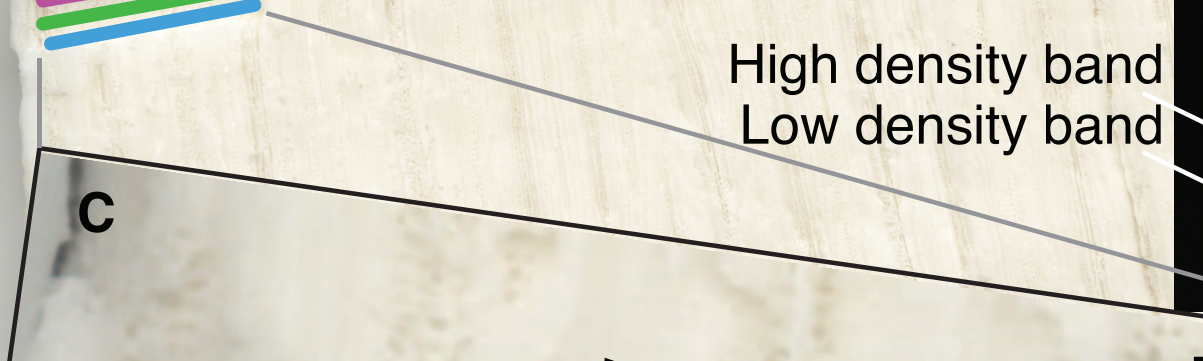

\section{B}

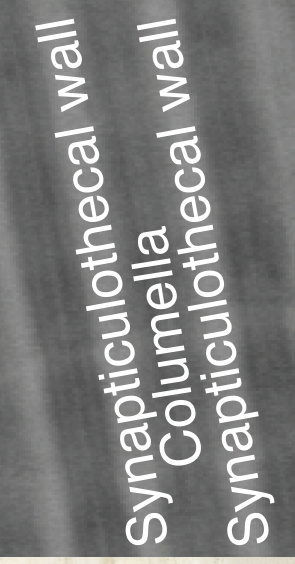

$\frac{\varepsilon^{\top}}{3}$

0

3

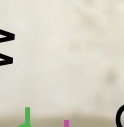

0

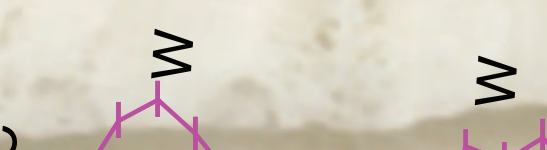

3

$7^{8.7 \mathrm{c}}$

Sample
paths
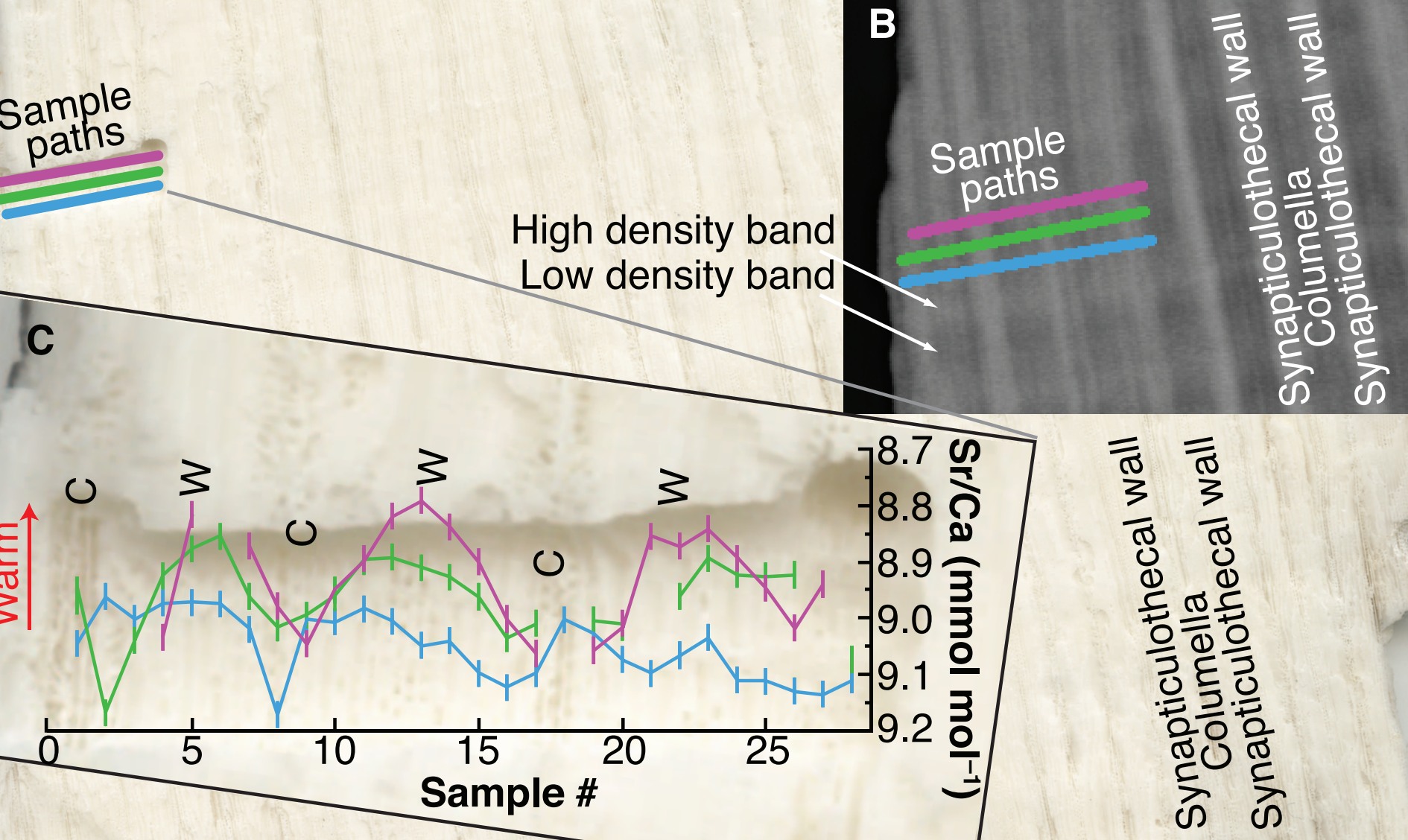
Figure 5

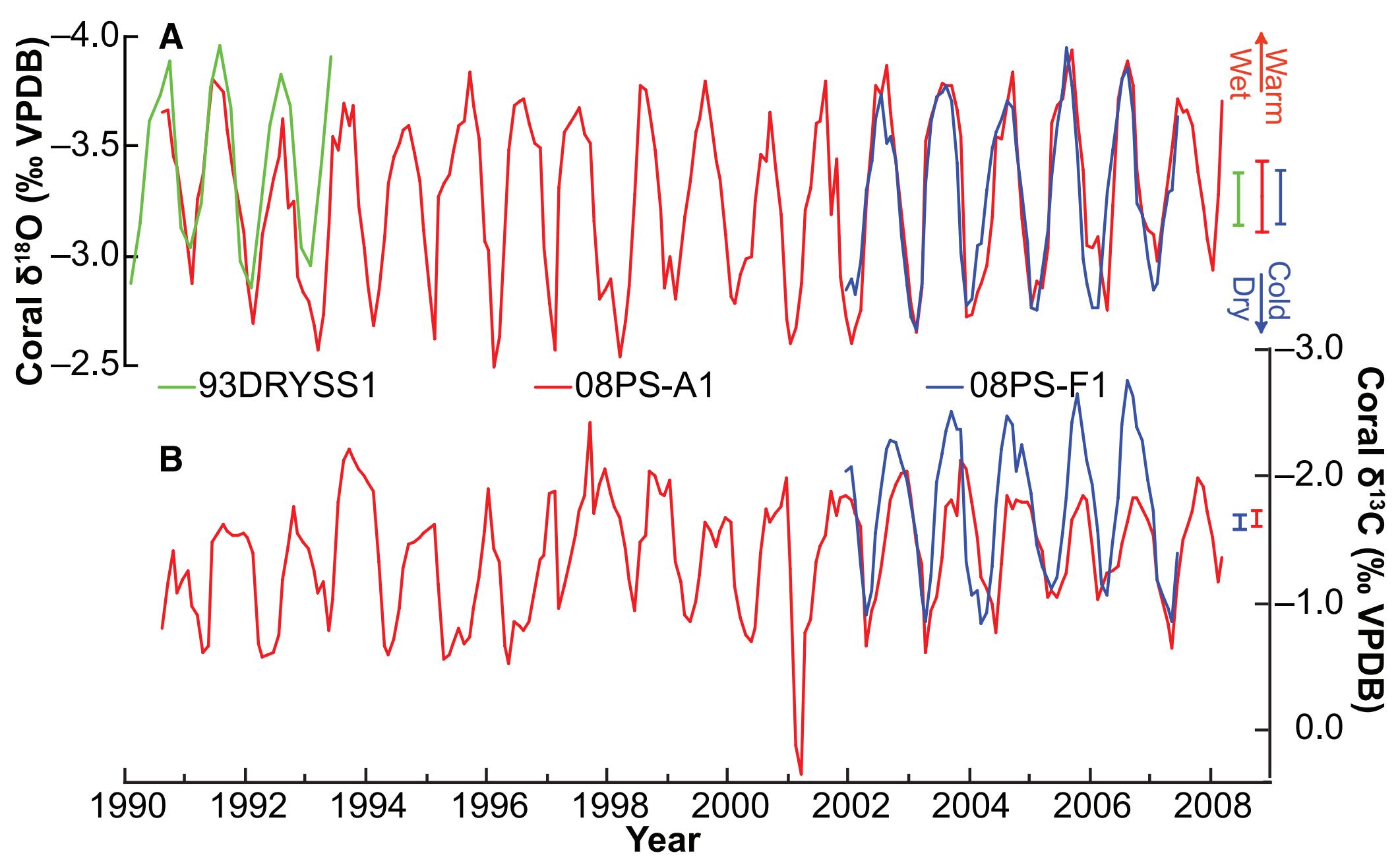




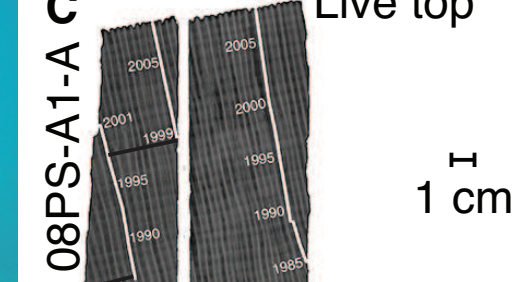

\section{PS-A1}

\section{PS-A2}

$>$

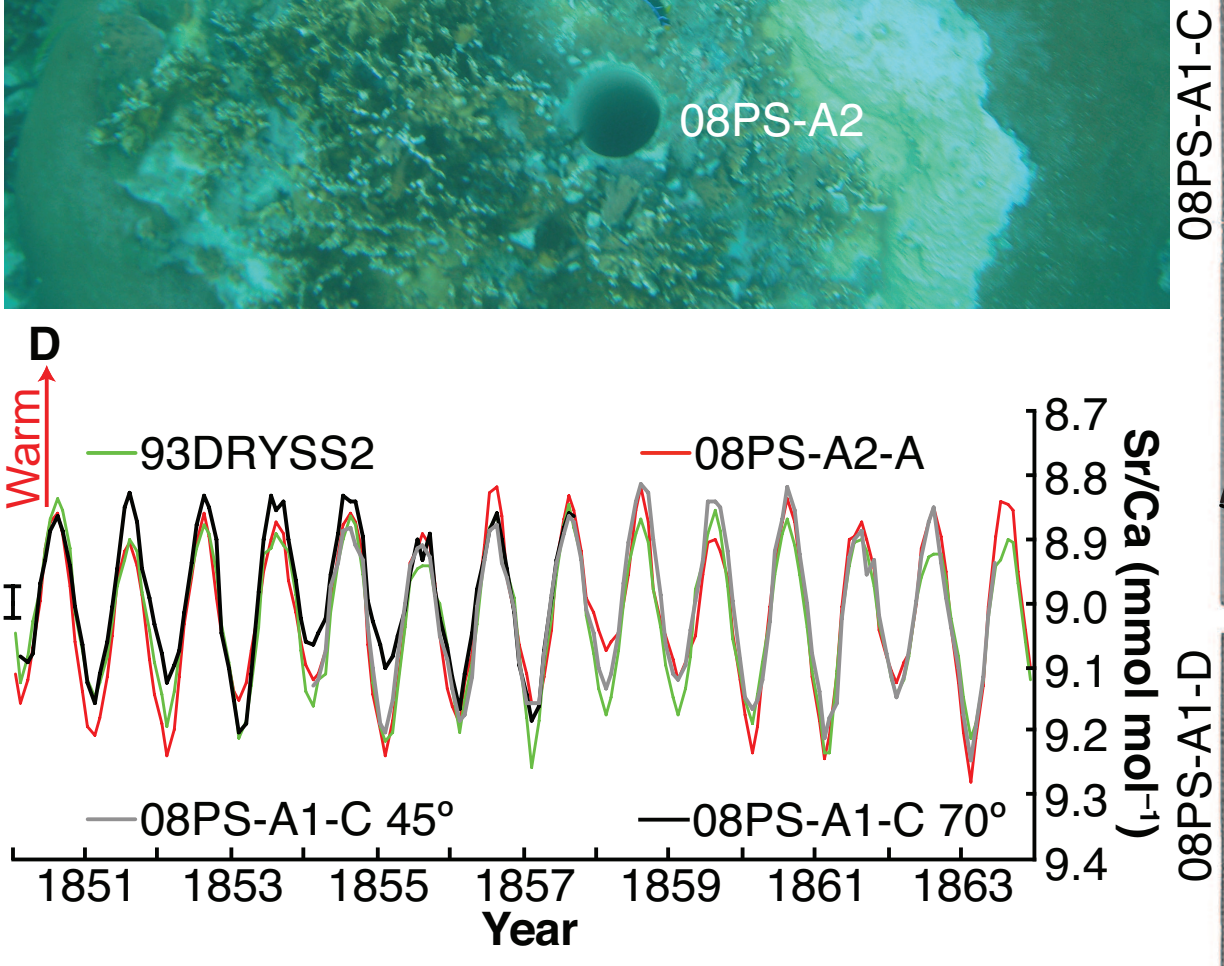

8.7 I

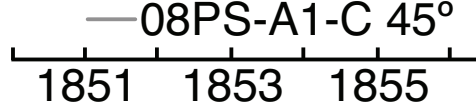
-08PS-A1-C 70

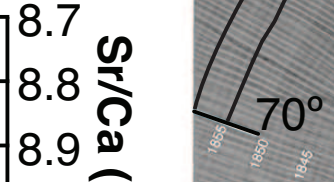
$-9.0 \widehat{\overline{3}}$ 9.1 으 무 -9.2 ํํ ष -9.3 은 卢 $\begin{array}{llll}1857 & 1859 & 1861 & 1863\end{array}$

Dead top

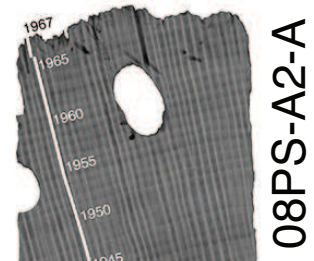

$m$
1
$\frac{1}{4}$
0
0
0
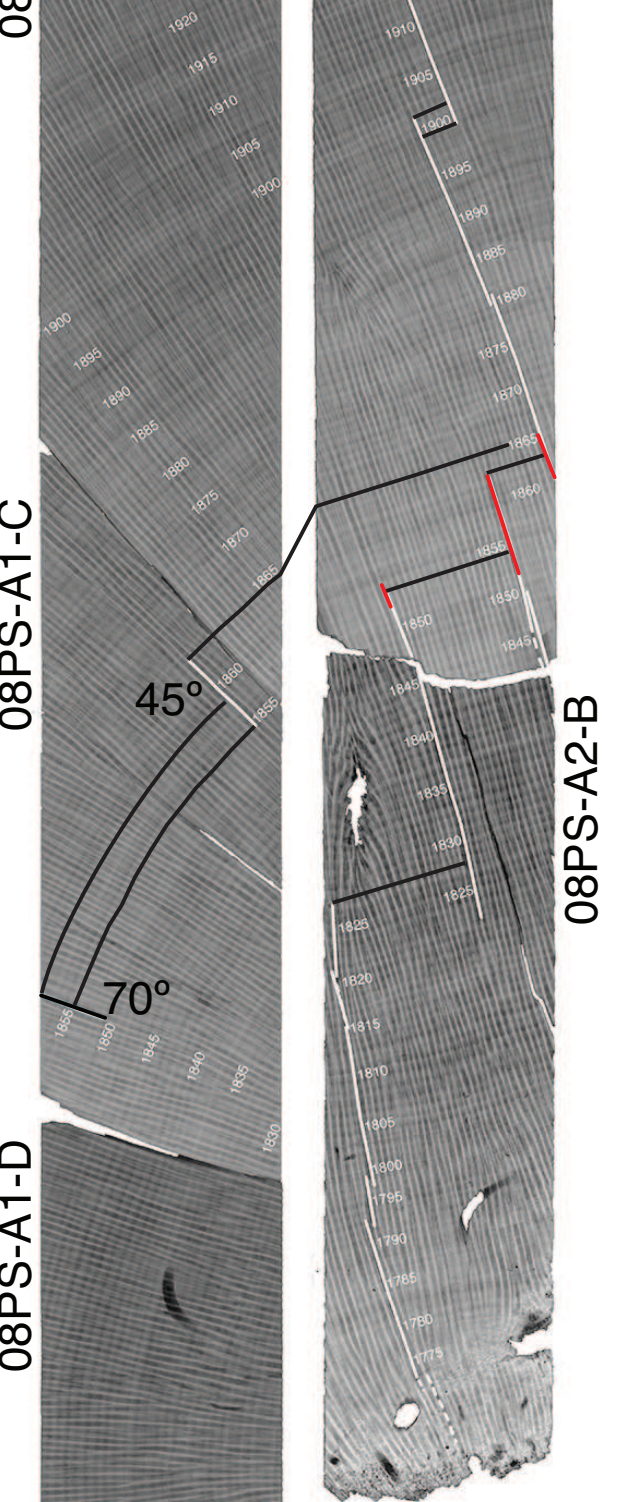


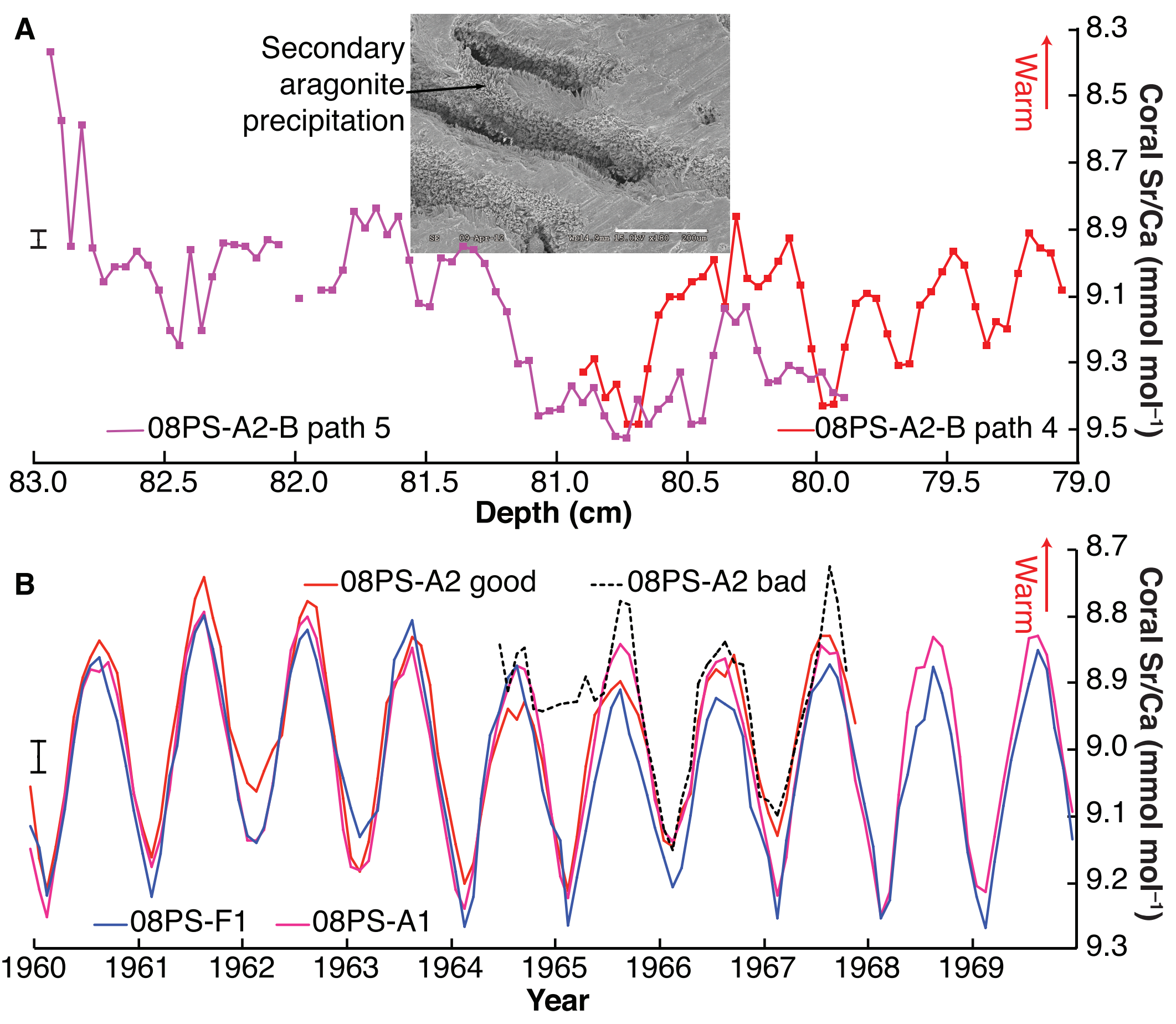




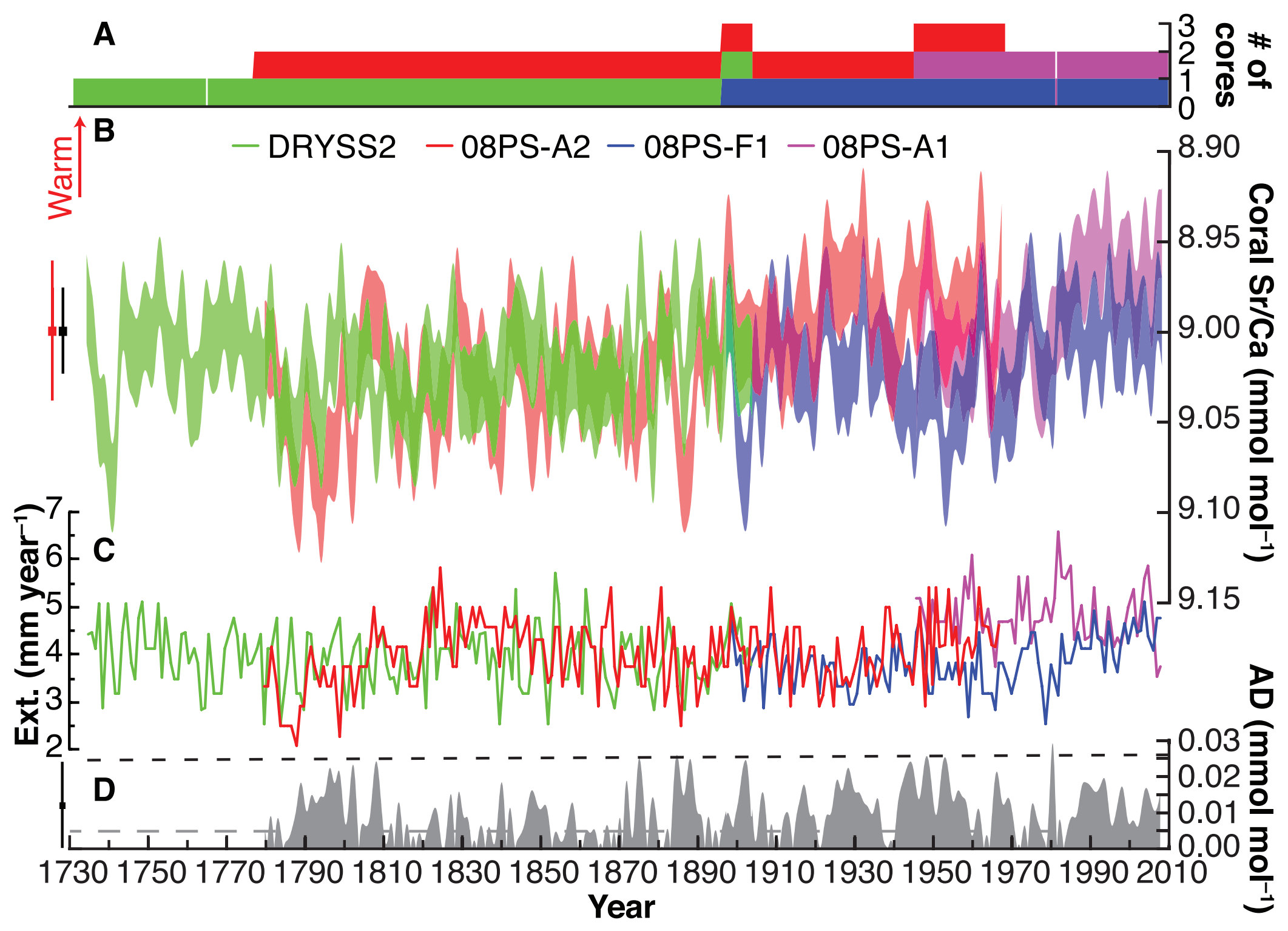

